\title{
New emission factors for Australian vegetation fires measured using open-path Fourier transform infrared spectroscopy - Part 1: Methods and Australian temperate forest fires
}

\author{
C. Paton-Walsh ${ }^{1}$, T. E. L. Smith ${ }^{2}$, E. L. Young ${ }^{1}$, D. W. T. Griffith ${ }^{1}$, and É.-A. Guérette ${ }^{1}$ \\ ${ }^{1}$ Centre for Atmospheric Chemistry, School of Chemistry, University of Wollongong, Wollongong, \\ New South Wales, Australia \\ ${ }^{2}$ King's College London, Earth and Environmental Dynamics Research Group, Department of Geography, Strand, \\ London, WC2R 2LS, UK
}

Correspondence to: C. Paton-Walsh (clarem@uow.edu.au)

Received: 11 November 2013 - Published in Atmos. Chem. Phys. Discuss.: 18 February 2014

Revised: 22 August 2014 - Accepted: 22 August 2014 - Published: 29 October 2014

\begin{abstract}
Biomass burning releases trace gases and aerosol particles that significantly affect the composition and chemistry of the atmosphere. Australia contributes approximately $8 \%$ of gross global carbon emissions from biomass burning, yet there are few previous measurements of emissions from Australian forest fires available in the literature. This paper describes the results of field measurements of trace gases emitted during hazard reduction burns in Australian temperate forests using open-path Fourier transform infrared spectroscopy. In a companion paper, similar techniques are used to characterise the emissions from hazard reduction burns in the savanna regions of the Northern Territory. Details of the experimental methods are explained, including both the measurement set-up and the analysis techniques employed. The advantages and disadvantages of different ways to estimate whole-fire emission factors are discussed and a measurement uncertainty budget is developed.

Emission factors for Australian temperate forest fires are measured locally for the first time for many trace gases. Where ecosystem-relevant data are required, we recommend the following emission factors for Australian temperate forest fires (in grams of gas emitted per kilogram of dry fuel burned) which are our mean measured values: $1620 \pm 160 \mathrm{~g} \mathrm{~kg}^{-1}$ of carbon dioxide; $120 \pm 20 \mathrm{~g} \mathrm{~kg}^{-1}$ of carbon monoxide; $3.6 \pm 1.1 \mathrm{~g} \mathrm{~kg}^{-1}$ of methane; $1.3 \pm 0.3 \mathrm{~g} \mathrm{~kg}^{-1}$ of ethylene; $1.7 \pm 0.4 \mathrm{~g} \mathrm{~kg}^{-1}$ of formaldehyde; $2.4 \pm 1.2 \mathrm{~g} \mathrm{~kg}^{-1}$ of methanol; $3.8 \pm 1.3 \mathrm{~g} \mathrm{~kg}^{-1}$ of acetic acid; $0.4 \pm 0.2 \mathrm{~g} \mathrm{~kg}^{-1}$ of formic acid; $1.6 \pm 0.6 \mathrm{~g} \mathrm{~kg}^{-1}$
\end{abstract}

of ammonia; $0.15 \pm 0.09 \mathrm{~g} \mathrm{~kg}^{-1}$ of nitrous oxide and $0.5 \pm 0.2 \mathrm{~g} \mathrm{~kg}^{-1}$ of ethane.

\section{Introduction}

Vegetation fires are a huge source of trace gases to the atmosphere, second only to fossil fuel combustion in their gross contribution to total global carbon emissions, with major implications for atmospheric chemistry on a global scale. On local to regional scales, the emissions from biomass burning can degrade air quality and impact negatively on human health. In Australia, average annual gross emissions of carbon from fires $\left(127 \mathrm{TgC}^{-1} \mathrm{r}^{-1}\right)$ actually exceeds that emitted by burning of fossil fuels $\left(95 \mathrm{TgC} \mathrm{yr}^{-1}\right)$ although net emissions from fires are only $26 \mathrm{TgC} \mathrm{yr}^{-1}$ due to the rapid regrowth that occurs, especially in savanna regions (Haverd et al., 2013).

The total quantity of emissions from vegetation fires varies enormously from year to year and, for this reason, fires are a major driver of variability in the composition of the troposphere. Accurate quantification of the emissions from vegetation fires is therefore crucial to realistic modelling of atmospheric composition on regional and global scales.

Emissions from fires are most commonly estimated using the algorithm of Seiler and Crutzen (1980), which multiplies together the total area burned in each fire and the assumed fuel loads, combustion efficiencies (the mass of dry 
vegetation burned per kilogram of fuel load) and emission factors (the mass of each species emitted per unit of dry vegetation burned). The availability of satellite-based measurements to define burned areas (Giglio et al., 2009) makes it possible to estimate fire emissions on a global scale using this technique, and thereby construct emissions inventories that serve as inputs to global models used to understand the atmospheric impacts of fires, e.g. Giglio et al. (2013) and van der Werf et al. (2006, 2010). Variations on the method for estimating burned area are used for fire emissions in Australia's National Greenhouse Gas Inventory (Australian Greenhouse Office, 2006), whilst the Fire INventory from NCAR (FINN) uses daily thermal hotspots detected by satellite-based sensors to estimate area burned (Wiedinmyer et al., 2011). Alternative methods for estimating emissions include model inversions constrained by satellite measurements of carbon monoxide (e.g. Pfister et al., 2005), fire radiative power (e.g. Wooster et al., 2003, 2005) or aerosol optical depth (e.g. Paton-Walsh et al., 2010a, 2012). In order to characterise the major emissions from vegetation fires, all these methods require knowledge of the emission factors for the relevant ecosystem.

The critical importance of emission factors for estimating fire emissions is problematic because there is a large range in the emission factors of most gases that are reported in reviews of the literature (e.g. Akagi et al., 2011; Andreae and Merlet, 2001). Andreae and Merlet (2001) produced the first compilation of emission factors measured from different ecosystems. They included as many measurements as were available at the time, converting measurements of ratios of different gases to equivalent emission factors for these gases where necessary. More recently, Akagi et al. (2011) produced an updated version that only included measurements made directly at the fires, excluding "enhancement ratios" measured down-wind of the fires. Both compilations report a very wide range of emission factors for individual ecosystems. This reflects both natural variability (driven by differences in vegetation cover, moisture content and fire intensity) and potential sampling biases from different studies that derive from different measurement geometries (see Sect. 4.2).

At any single location within the fire, combustion can be thought of as progressing from a flaming stage through to a smouldering stage. Flaming combustion results in larger proportions of highly oxidised species such as $\mathrm{CO}_{2}$ and $\mathrm{NO}_{\mathrm{x}}$, whilst emissions from smouldering combustion contain more $\mathrm{CO}, \mathrm{NH}_{3}$ and volatile organics. For this reason, the emission factors depend on the balance of flaming and smouldering combustion that occurs throughout the fire (Andreae and Merlet, 2001). Species emitted during the rapid and intense flaming stage are lofted by convection, whilst many other trace gases are emitted predominantly through the slow and sometimes prolonged smouldering stage. Open-path Fourier transform infrared (FTIR) spectroscopy is a ground-based technique that measures the concentration of trace gases integrated over a path length of many metres. Despite being a ground-based technique, it has the potential to operate in geometries that capture flaming emissions as they are lofted above the fire and continue to measure the emissions through the smouldering stages of the burn. Open-path FTIR spectroscopy was first used to measure mole fractions of gasphase species in open biomass burning smoke in the USA by Griffith et al. (1991). It has been used in several subsequent studies (e.g. Akagi et al., 2013, 2014; Goode et al., 1999, 2000; Wooster et al., 2011; Yokelson et al., 1996, 1997), but has not been used before for field measurements of trace gas emissions from Australian forest fires.

The type of combustion that occurs, and hence the mixture of trace gases that are released, is heavily dependent on factors such as the fuel type, load, moisture and arrangement and on environmental conditions such as temperature and humidity. Fire intensity, which is in part governed by these prior factors, also plays a significant role in influencing emissions (Andreae and Merlet, 2001; Yokelson et al., 1999). These factors have considerable spatial and temporal variability. For this reason, emission factors may differ significantly from one ecosystem to another.

It has been estimated that Australia contributes $\sim 8 \%$ of the total global carbon emissions from biomass burning (Ito and Penner, 2004), and yet there have been relatively few measurements made of emissions from Australian fires. Interest has focused predominantly on the northern savanna regions where large areas burn every year (Hurst et al., 1994a, b; Meyer et al., 2012; Shirai et al., 2003). There are some other measurements in the literature that report emission ratios or enhancement ratios measured in fresh and aged Australian savanna fire smoke, respectively. However, these may only be converted to equivalent emission factors by using an assumed emission factor for the reference gas (e.g. Pak et al., 2003; Paton-Walsh et al., 2010b).

The scarcity of previous measurements in the scientific literature is even more pronounced for Australian forest fires, where the only directly measured emission factors are from aircraft-based samples by Hurst et al. (1996) for a subset of gases. There are a number of other studies that present enhancement ratios measured in aged smoke using either ground-based solar remote sensing Fourier transform spectrometry or satellite-based spectroscopic measurements (Glatthor et al., 2013; Paton-Walsh et al., 2004, 2005; Young and Paton-Walsh, 2011). For conversion to an equivalent emission factor, these measured enhancement ratios require an assumed emission factor for $\mathrm{CO}$, which introduces large uncertainties to the emission factors for these fires. Additionally, concentrations of gases have been measured in smoke from Australian forest fires to assess the exposure levels of firefighters and rural populations exposed to bushfire smoke (Reisen and Brown, 2009; Reisen et al., 2011). A study that identified emissions from eucalyptus species at high temperatures and during combustion produced no quantitative mole fractions, nor any emission factors (Maleknia et al., 2009). 


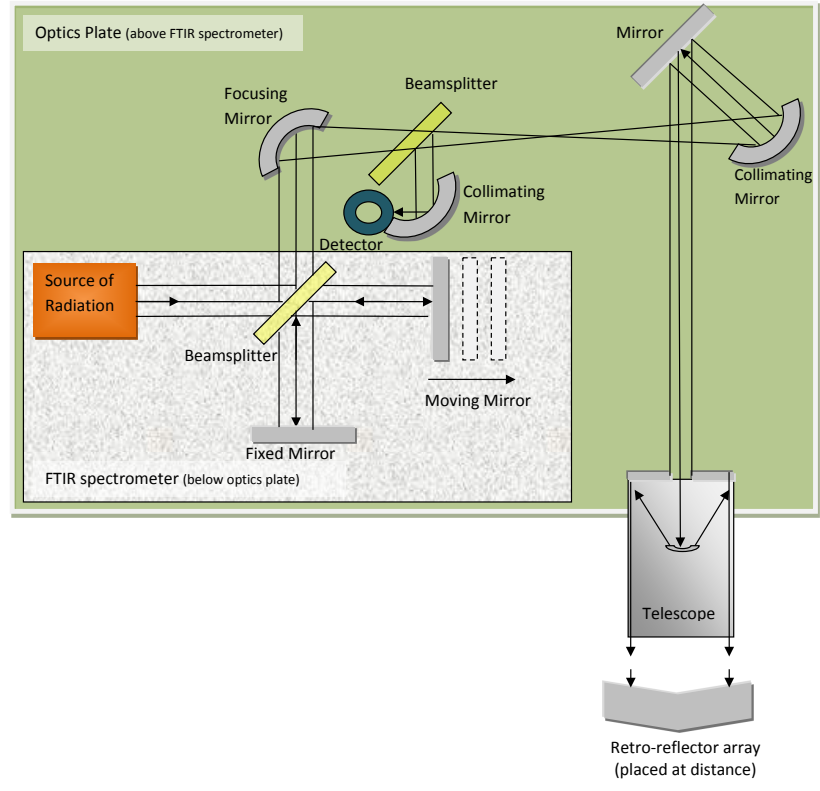

Figure 1. Schematic of the instrumental set-up, showing a basic Fourier transform spectrometer and the optics mounted on the top plate to steer the modulated radiation from the spectrometer through the telescope to the distant retro-reflector array and back again to be focused onto the detector.

The work described in this paper aims to contribute to the sparse base of knowledge concerning the atmospheric emissions from Australian temperate forest fires. Open-path FTIR spectroscopy was used for field measurements of trace gases emitted during five different hazard reduction burns in Australian temperate forests in 2010 and 2012. In a partner paper, similar techniques are employed to provide new emission factors from Australian savanna fires (Smith et al., 2014).

\section{Open-path Fourier transform infrared spectroscopic measurement techniques}

\subsection{The open-path FTIR system}

The open-path FTIR system operated by the University of Wollongong consists of a Bomem MB-100 Series FTIR spectrometer $\left(1 \mathrm{~cm}^{-1}\right.$ resolution), fitted with a Meade $12^{\prime \prime}$ (305 mm) LX300 telescope. The spectrometer is equipped with a built-in infrared source so that the infrared radiation is modulated within the spectrometer before being sent out through the telescope to the distant retro-reflectors, typically located 20 to $50 \mathrm{~m}$ away. It is then returned through the telescope - and the fraction of the radiation that is reflected by the external beam splitter is focused onto the liquid-nitrogencooled Mercury Cadmium Telluride detector (see Fig. 1) (Phillips et al., 2011).

This "monostatic" configuration, shown in Fig. 1, has significant advantages over the often used "bistatic" configura- tion (where a distant collimated infrared source is imaged by a telescope onto the entrance aperture of the spectrometer) because there is no requirement to correct for radiation emitted by the surrounding environment (see Bacsik et al., 2004). This is because the radiation from the surrounding environment is not modulated by the interferometer in this arrangement and therefore appears only as a direct current signal on the detector (and thus has no significant impact on the resulting spectrum). Pre-modulation of the radiation source is especially important when measuring flaming combustion because the strong radiation emitted by the flames does not appear in the Fourier transform spectrum. Our monostatic configuration allows measurement even through flames thereby avoiding biases that result if spectra that are recorded through flames need to be discarded. Nevertheless, problems can still arise with the spectroscopy of very hot gases, if the temperature is not well defined.

The spectrometer was mounted on a tripod such that the line of sight was approximately $1.5 \mathrm{~m}$ above the ground and aligned with a retro-reflector positioned in the field (typically between 20 and $40 \mathrm{~m}$ from the spectrometer). Single beam spectra were recorded approximately every $20 \mathrm{~s}$ (by coadding three scans per spectrum) before and during each burn at $1.0 \mathrm{~cm}^{-1}$ resolution.

\subsection{Quantitative analysis of infrared spectra}

Trace gas mole fractions were calculated from all open-path FTIR spectra using the Multiple Atmospheric Layer Transmission (MALT) program (Griffith, 1996). MALT calculates "synthetic" spectra to closely match measured spectra using an initial estimate of the amount of each gas present in the measurement path, as well as a combination of absorption line parameters (from the 2008 HITRAN database for this work) (Rothman et al., 2009). The synthetic spectra are iteratively recalculated (using a non-linear least squares method that adjusts the estimated amount of each species present) until the difference between the measured spectra and the synthetic spectra is minimised (the best fit is achieved). A more comprehensive description of MALT can be found in Griffith (1996) and Griffith et al. (2012). The use of synthetic spectra has been proven as an accurate method for quantitative trace gas analysis over a broad range of mole fractions, ranging from those found in the ambient atmosphere to those in highly polluted atmospheres such as biomass burning smoke plumes (Smith et al., 2011). In that study Smith et al. (2011) compared MALT trace gas retrieved amounts from spectra collected using open-path FTIR spectroscopy to true known amounts using calibration gases in a large gas cell. They reported MALT retrievals accurate to within $5 \%$ of the true amounts when the environmental parameters are accurately specified. MALT also uses the values of pressure, temperature and path length provided to convert from the retrieved path length amounts to mole fraction of each species, usually expressed in $\mu \mathrm{mol} \mathrm{mol}^{-1}$ (ppm) or $\mathrm{nmol} \mathrm{mol}^{-1}$ (ppb). 


\subsection{Spectral regions and parameters for quantitative analysis of trace gases in highly polluted environments}

As part of this study, we defined a set of standardised spectral regions that can be used for each of the trace gases of interest. This was done with spectra from the monostatic configuration described above and spectra from the bistatic instrument configuration used in the savanna fires and described in our partner paper (Smith et al., 2014). We have chosen spectral windows and fitting parameters that optimise the stability of the retrieval and minimise the residuals to the fits (the differences between the measured and the best fitted synthetic spectra) for these two very different instrumental setups. Optimised spectral windows are dependent upon many factors, including path length, spectral resolution, humidity and the concentration range of the species retrieved and any interfering species. The spectral regions and fitting parameters presented here would be a useful starting point for new groups employing open-path FTIR spectrometry to measure in similar highly polluted atmospheric environments.

The spectral regions are chosen to contain the most sensitive absorption features of the trace gases of interest (i.e. neither too weak to be detected above the spectral noise of the continuum level, nor too saturated to change with the further addition of more absorbing molecules). The chosen regions are similar but not identical to those used in Akagi et al. (2014). Any unavoidable interfering species that were absorbing in the specified spectral region were accounted for by fitting them at the same time. The standardised spectral regions chosen for each trace gas of interest in this work are described in detail in Appendix A and summarised in Table 1, with typical fits achieved shown in Fig. 2.

\section{Hazard reduction burns}

In total, five hazard reduction burns were attended in this study, with two fires in 2010 and three in 2012. All fires were located in New South Wales (NSW) and were conducted by the NSW National Parks \& Wildlife Service, often with the assistance of volunteer rural fire services. 2011 was a year with unusually high rainfall (Cottrill, 2012; Tobin and Skinner, 2012) and, despite several burns planned in the region, no fires were successfully sampled. Vegetation types burned in this study included eucalypt woodland forest, banksia/hakea heath and sclerophyll forest, shrub and woodland. Estimated fuel loadings (before the fires) varied from 8-10 tonnes per hectare $\left(\mathrm{tha}^{-1}\right)$ to $20-25 \mathrm{tha}^{-1}$ and the total area burned varied from 4.8 ha to as much as 148.5 ha (S. Evans, personal communication, 2012). In all instances, only a subset of the total fuel burned could be sampled by the methods described here, with measurements made over several hours and in one case spanning two days of burning.
A brief overview of each fire attended is given below and the main details are summarised in Table 2.

\subsection{Lane Cove hazard reduction burn}

The first hazard reduction burn measurements were made on the 31 August 2010 at Max Allen Drive at the NSW Parks \& Wildlife Service's depot at Lane Cove $\left(33.79^{\circ} \mathrm{S}\right.$, $\left.151.15^{\circ} \mathrm{E}\right)$. The spectrometer was positioned at the bottom of a steep slope at the depot itself, with the telescope pointing up the hill towards the retro-reflector array positioned $\sim 53 \mathrm{~m}$ away at the edge of the access road. The total optical path length from infrared source to detector was estimated to be $107 \pm 2 \mathrm{~m}$. The geometric arrangement was such that both smoke and flames passed through the line of sight, making the pre-modulated source essential for this set-up (see Fig. 3a).

\subsection{Turramurra hazard reduction burn}

The second of the burns attended was at Gibberagong, North Turramurra in Ku-Ring-Gai Chase National Park on the 28 September 2010. This was the largest of all the hazard reduction burns attended in this study, with a total of 148.5 hectares of banksia and hakea heath and sclerophyll shrub forest burned. Over 50 firefighters, 3 fire engines and two helicopters were deployed for the fire with one helicopter dropping incendiary bombs and the other water bombing to prevent the spread of the fire beyond the intended boundaries of the burn.

The spectrometer's telescope and retro-reflectors were set up $\sim 42 \mathrm{~m}$ apart on a fire trail at the perimeter of the fireground and downwind of the flames (see Fig. 3b), with a total path length of $84 \pm 2 \mathrm{~m}$. This geometry required the smoke to be blown into the measurement path nearby and as such may be biased towards smouldering combustion since some of the emissions from flaming stages of the burn may have been lofted by convection above the line of sight of the spectrometer. However, for a significant part of the measurement period, there was flaming combustion of vegetation on the edge of the fire trail where the spectrometer and retroreflector were positioned such that some flaming combustion emissions were sampled.

\subsection{Abaroo Creek hazard reduction burn}

The Abaroo Creek hazard reduction burn took place over two consecutive days (11-12 May 2012) in Heathcote National Park. The northern end of the fireground $\left(34.10^{\circ} \mathrm{S}\right.$, $150.99^{\circ} \mathrm{E}$ ) was ignited on the 11 May, and the spectrometer and retro-reflectors were set up $43 \mathrm{~m}$ apart $(86 \pm 2 \mathrm{~m}$ path length) on the side of the main road into Sydney from the south that bounded the fireground downwind of and adjacent to the fires (see Fig. 3c). Further ignition was achieved by the use of incendiary devices dropped from a helicopter flying overhead. Smoke and flames from nearby tea trees crossed 
Table 1. Spectral regions used for trace gas retrievals and trace gas species fitted.

\begin{tabular}{llll}
\hline Trace gas(es) of interest & Interfering species fitted & Spectral region fitted $\left(\mathrm{cm}^{-1}\right)$ & Fit to continuum-level, instrument line shape \\
\hline $\mathrm{CO}^{2}$ and $\mathrm{CO}_{2}$ (and $\left.\mathrm{N}_{2} \mathrm{O}\right)^{1}$ & $\mathrm{H}_{2} \mathrm{O}$ & $2080-2270$ & Second-order polynomial fit phase, eff. apodisation \\
$\mathrm{CH}_{4}$ & $\mathrm{H}_{2} \mathrm{O}$ & $2980-3105$ & Second-order polynomial fit phase, eff. apodisation \\
$\mathrm{C}_{2} \mathrm{H}_{4}$ and $\mathrm{NH}_{3}$ & $\mathrm{H}_{2} \mathrm{O}$ & $920-1000$ & Second-order polynomial fit phase, eff. apodisation \\
$\mathrm{H}_{2} \mathrm{CO}$ & $\mathrm{H}_{2} \mathrm{O}$ & $2730-2800$ & Second-order polynomial fit phase, fix eff. apodisation \\
$\mathrm{CH}_{3} \mathrm{OH}$ & $\mathrm{H}_{2} \mathrm{O}, \mathrm{NH}_{3}$ & $1020-1055$ & Second-order polynomial fit phase, fix eff. apodisation \\
$\mathrm{HCOOH}$ & $\mathrm{H}_{2} \mathrm{O}, \mathrm{NH}_{3}$ & $1060-1150$ & Second-order polynomial fit phase, eff. apodisation \\
$\mathrm{CH}_{3} \mathrm{COOH}$ & $\mathrm{H}_{2} \mathrm{O}, \mathrm{NH}_{3}, \mathrm{HCOOH}$ & $1130-1230$ & Slope only (1st order) fit phase, eff. apodisation \\
$\mathrm{C}_{2} \mathrm{H}_{6}^{3}$ & $\mathrm{H}_{2} \mathrm{O}, \mathrm{CH}_{4}, \mathrm{C}_{2} \mathrm{H}_{4}$ & $2971-3002$ & Second-order polynomial fit phase, fix eff. apodisation \\
$\mathrm{C}_{2} \mathrm{H}_{2}$ and $\mathrm{HCN}^{4}$ & $\mathrm{H}_{2} \mathrm{O}, \mathrm{CO}_{2}$ & $710-760$ & Second-order polynomial fit phase, fix eff. apodisation \\
\hline
\end{tabular}

${ }_{1}$ Accurate $\mathrm{N}_{2} \mathrm{O}$ retrievals are difficult as the features lie under the stronger bands of $\mathrm{CO}$ and ${ }^{13} \mathrm{CO}_{2}$.

2 Uses a library spectrum as HITRAN lines are not available.

${ }^{3} \mathrm{C}_{2} \mathrm{H}_{6}$ features are very weak and can only be retrieved accurately at higher concentrations than were usual at these burns.

${ }^{4} \mathrm{C}_{2} \mathrm{H}_{2}$ and $\mathrm{HCN}$ - this window was used for spectra recorded with the bi-static instrumentation used at the savanna burns only. The mono-static instrumentation described in this paper used a detector with insufficient sensitivity at these longer wavelengths for this retrieval.

Table 2. Summary of hazard reduction burns where measurements were made, including location, date, vegetation type, burned area, fuel loading before burn along with the hours of burning sampled, the total number of fire-influenced spectra collected and the peak mole fractions of $\mathrm{CO}_{2}$ and $\mathrm{CO}$ measured.

\begin{tabular}{|c|c|c|c|c|c|c|c|}
\hline Fire name, location (latitude, longitude) & Date & $\begin{array}{l}\text { Vegetation/fuel } \\
\text { description }\end{array}$ & $\begin{array}{l}\text { Area } \\
\text { burned } \\
\text { (ha) }\end{array}$ & $\begin{array}{l}\text { Fuel loading } \\
\left(\text { tha }^{-1}\right)\end{array}$ & $\begin{array}{l}\text { Number of } \\
\text { fire spectra }\end{array}$ & $\begin{array}{l}\text { Hours of burn- } \\
\text { ing sampled }\end{array}$ & $\begin{array}{l}\text { Peak path-averaged } \\
\mathrm{CO}_{2} \text { and } \mathrm{CO} \\
\text { measured }\end{array}$ \\
\hline $\begin{array}{l}\text { Max Allen Drive, Lane Cove National } \\
\text { Park, NSW }\left(33.79^{\circ} \mathrm{S}, 151.15^{\circ} \mathrm{E}\right)\end{array}$ & 31 Aug 2010 & $\begin{array}{l}\text { Dry sclerophyll open } \\
\text { woodland }\end{array}$ & 4.8 & $18-26$ & 270 & $2 \mathrm{~h}, 31 \mathrm{~min}$ & $\begin{array}{l}\sim 800 \mathrm{ppm} \mathrm{CO}_{2} \\
\sim 30 \mathrm{ppm} \mathrm{CO}\end{array}$ \\
\hline $\begin{array}{l}\text { Gibberagong, North Turramurra, Ku- } \\
\text { Ring-Gai Chase National Park, NSW } \\
\left(33.67^{\circ} \mathrm{S}, 151.15^{\circ} \mathrm{E}\right)\end{array}$ & 28 Sep 2010 & $\begin{array}{l}\text { Banksia/Hakea heath } \\
\text { and Sclerophyll } \\
\text { shrub forest }\end{array}$ & 148.5 & $20-25$ & 232 & $2 \mathrm{~h}, 6 \mathrm{~min}$ & $\begin{array}{l}\sim 900 \mathrm{ppm} \mathrm{CO}_{2} \\
\sim 55 \mathrm{ppm} \mathrm{CO}\end{array}$ \\
\hline $\begin{array}{l}\text { Abaroo Creek, Heathcote National } \\
\text { Park, NSW: North end }\left(34.10^{\circ} \mathrm{S} \text {, }\right. \\
\left.150.99^{\circ} \mathrm{E}\right) \text { and } \\
\text { South end: }\left(34.13^{\circ} \mathrm{S}, 150.99^{\circ} \mathrm{E}\right)\end{array}$ & $\begin{array}{l}11 \text { May } 2012 \\
\text { and } \\
12 \text { May } 2012\end{array}$ & $\begin{array}{l}\text { Shrubby dry } \\
\text { schlerophyll } \\
\text { forest/heathland }\end{array}$ & $115^{\mathrm{a}}$ & 12.5 & $\begin{array}{l}344 \\
\text { and } \\
278\end{array}$ & $\begin{array}{l}2 \mathrm{~h}, 3 \mathrm{~min} \\
\text { and } \\
2 \mathrm{~h}, 22 \mathrm{~min}\end{array}$ & $\begin{array}{l}\sim 800 \mathrm{ppm} \mathrm{CO}_{2} \\
\sim 40 \mathrm{ppm} \mathrm{CO}\end{array}$ \\
\hline $\begin{array}{l}\text { Gulguer Nature Reserve, NSW } \\
\left(33.95^{\circ} \mathrm{S}, 150.62^{\circ} \mathrm{E}\right)\end{array}$ & 16 May 2012 & $\begin{array}{l}\text { Open eucalypt } \\
\text { woodland forest with } \\
\text { grassy understorey }\end{array}$ & 32 & $8-10$ & 333 & $2 \mathrm{~h}, 6 \mathrm{~min}$ & $\begin{array}{l}\sim 2200 \mathrm{ppm} \mathrm{CO}_{2} \\
\sim 140 \mathrm{ppm} \mathrm{CO}\end{array}$ \\
\hline $\begin{array}{l}\text { Alfords Point, Georges River National } \\
\text { Park, NSW, }\left(33.99^{\circ} \mathrm{S}, 151.02^{\circ} \mathrm{E}\right)\end{array}$ & 23 May 2012 & $\begin{array}{l}\text { Shrubby dry } \\
\text { schlerophyll forest }\end{array}$ & 18 & $14-18$ & 496 & $3 \mathrm{~h}, 6 \mathrm{~min}$ & $\begin{array}{l}\sim 3400 \mathrm{ppm} \mathrm{CO}_{2} \\
\sim 180 \mathrm{ppm} \mathrm{CO}\end{array}$ \\
\hline
\end{tabular}

a Total area burned in Heathcote National Park, NSW, over the two days.

${ }^{b}$ Hours of burning sampled is the difference between the time that the first and last smoke-affected spectra were recorded. In some cases spectra were lost during this time due to fire trucks or fire fighters obscuring the measurement path or excluded due to temperature errors or insufficient enhancements over background values.

the measurement path fanned by winds from the northwest. The proximity to the road could also have produced some interfering pollution from cars slowed by traffic controllers and the smoke blowing across the road.

The southern end of the Abaroo Creek fireground $\left(34.13^{\circ} \mathrm{S}, 150.99^{\circ} \mathrm{E}\right)$ was ignited on the 12 May. The spectrometer and retro-reflectors were set up $31 \mathrm{~m}$ apart $(62 \pm 2 \mathrm{~m}$ path length) at the muster point on the fire trail close to the ignition point. The muster point was an open area of approximately $100 \mathrm{~m}$ length and $30 \mathrm{~m}$ width with the fires being burned either side.

Vegetation to the east of our measurement path was ignited first and, at the time of ignition, there was a slight westerly breeze so that little of the emissions from this area were sampled by the spectrometer. Unfortunately, the breeze had dropped away by the time the area to our west was ignited, so our line of path was not ideally located downwind of the burning vegetation (see Fig. 3d). Nevertheless, significant enhanced mole fractions were measured along the optical path allowing emission factors to be calculated, but we suspect a bias towards smouldering combustion. Results from both days of burning at Abaroo Creek have been combined in an attempt to yield a more representative sample of flaming and smouldering combustion.

\subsection{Gulguer Nature Reserve hazard reduction burn}

Gulguer Nature Reserve $\left(33.95^{\circ} \mathrm{S}, 150.62^{\circ} \mathrm{E}\right)$ is an area of open eucalypt woodland forest with a grassy understorey. The hazard reduction burn took place on the 16 May 2012, with the spectrometer and telescope located on a fire trail and the retro-reflectors placed $19 \mathrm{~m}$ away ( $38 \pm 2 \mathrm{~m}$ path length) 


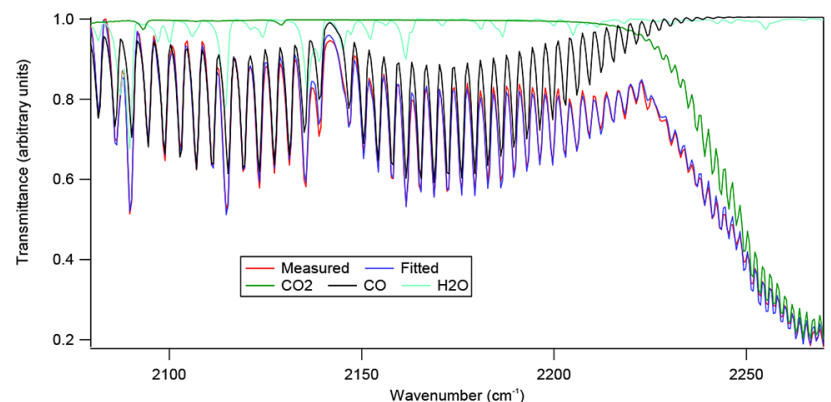

(a)

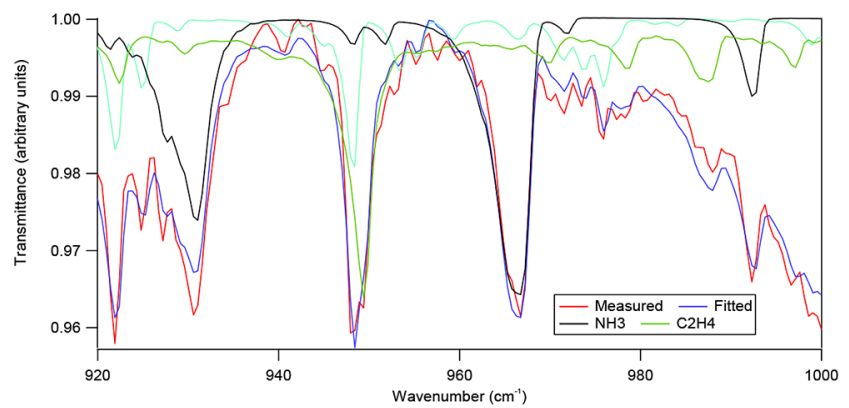

(c)

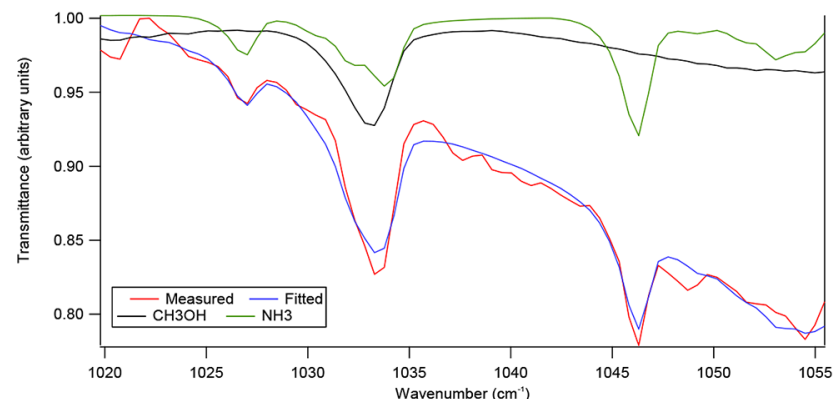

(e)

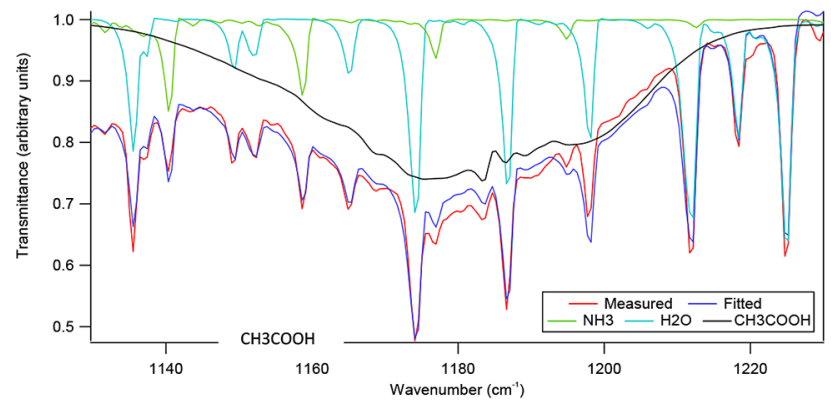

$(\mathrm{g})$

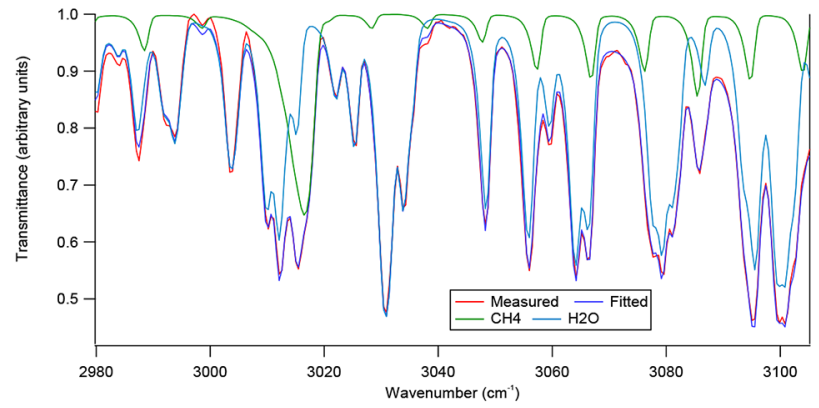

(b)

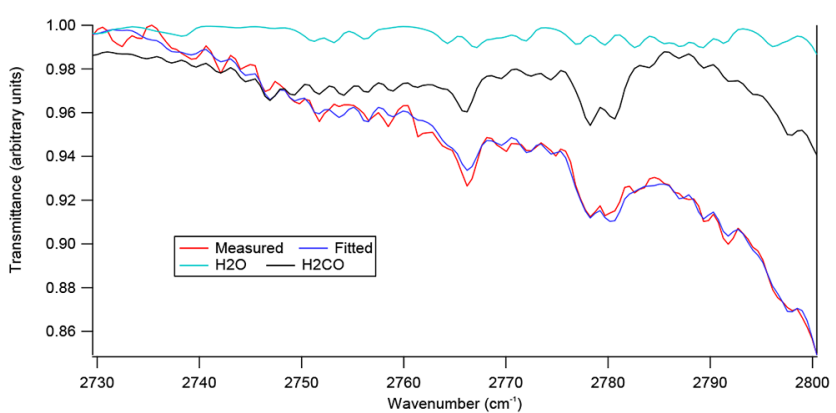

(d)

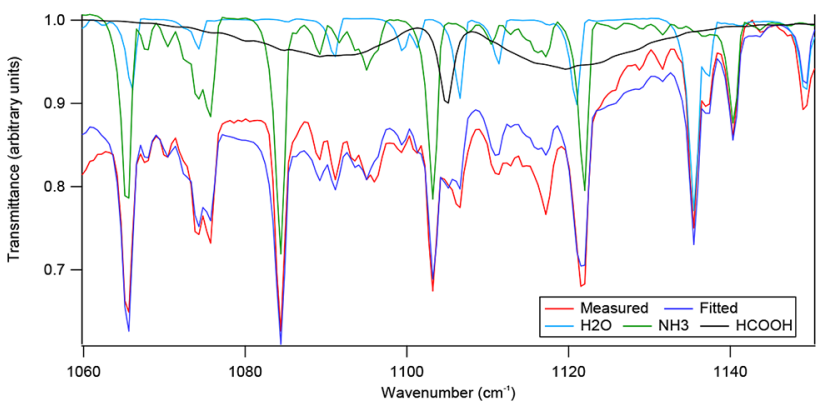

(f)

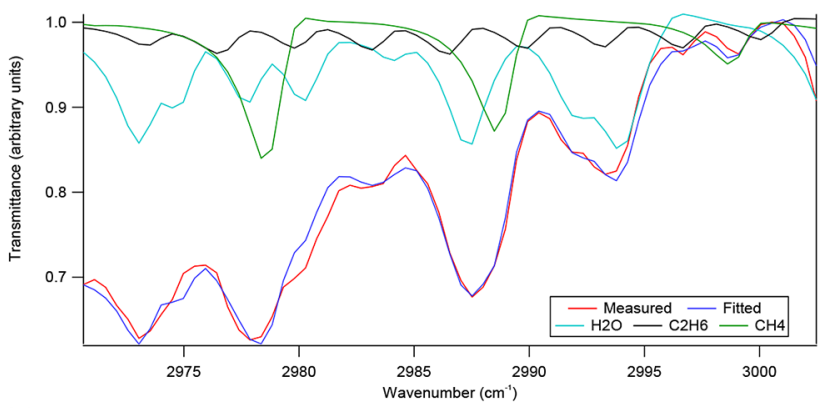

(h)

Figure 2. Plots of MALT fits of simulated to measured spectra. The main gases contributing to the absorption features in each spectral region are also shown.

within the woodland area being burned (see Fig. 3e). In this geometry, flaming and smouldering emissions are sampled together, with less potential for bias towards the smouldering emissions. The burn took hold easily and plenty of smoke was sampled in the measurement path.

\subsection{Alfords Point hazard reduction burn}

The Alfords Point burn occurred in somewhat unusual circumstances for a hazard reduction burn, with a strong breeze blowing towards the face of a steep escarpment, and the fire 


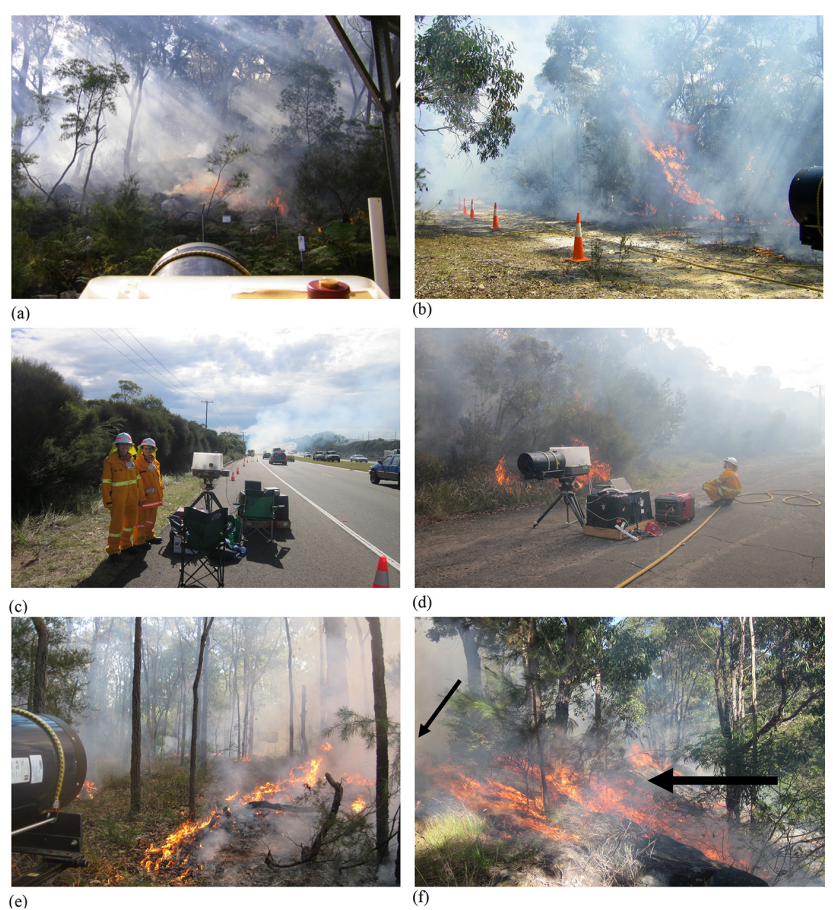

Figure 3. The instrumental set-up for open-path FTIR measurements of smoke at the different burns is shown: (a) Max Allen Drive; (b) Gibberagong; (c) Abaroo Creek (Day 1); (d) Abaroo Creek (Day 2); (e) Gulguer Nature Reserve and (f) Alfords Point.

being first ignited near the top. The firefighters worked by igniting the fire in approximately $15 \mathrm{~m}$ strips and allowing it to burn upwards towards a fire trail at the top, in front of a number of residential buildings. The spectrometer, telescope and retro-reflectors were set up $\sim 42 \mathrm{~m}$ apart $(84 \pm 2 \mathrm{~m}$ path length) immediately leeward of the steep escarpment and away from any of the nearby homes. The strength of the wind was sufficient to push the flames towards the measurement path, ensuring an excellent geometry to capture a good mixture of emissions representative of all states of burning occurring in the fire. This is illustrated in the photograph taken at the site shown in Fig. 3f.

Fanned by the wind, the fire burned well and the geometry of the measurement set-up resulted in very high mole fractions of trace gases being sampled in the measurement path. Despite personal protective equipment (goggles and masks), the smoke and heat became too intense for us to stay with the spectrometer throughout the measurement period; however once set up, the open-path spectrometer ran autonomously and continued to record spectra through the thick smoke.

\section{Methods for calculating emission factors}

\subsection{Calculating emission factors and modified combustion efficiency}

The emission factor $\left(\mathrm{EF}_{i}\right)$ is the mass of a gaseous species $(i)$ emitted per unit of dry fuel consumed, usually expressed in units of $\mathrm{g} \mathrm{kg}^{-1}$. When the measurements include the species that contain the majority of the carbon that is emitted by the fires, then approximate emission factors for each of the trace gases of interest can be calculated using the method previously used by Ward and Radke (1993):

$\mathrm{EF}_{i}=F_{\mathrm{c}} \times 1000 \times \frac{\mathrm{MM}_{i}}{12} \times \frac{C_{i}}{C_{\mathrm{T}}}$,

where $\mathrm{EF}_{i}$ is the mass in grams of species $i$ emitted per kilogram of dry fuel burned $\left(\mathrm{g} \mathrm{kg}^{-1}\right), F_{\mathrm{c}}$ is the fractional carbon content of the fuel (assumed here to be $0.50 \pm 0.05$ for all hazard reduction burns (Yokelson et al., 1999), $\mathrm{MM}_{i}$ is the molecular mass of species $i$, with 12 the atomic mass of carbon and $C_{i} / C_{\mathrm{T}}$ is the number of moles of species $i$ emitted divided by the total number of moles of carbon emitted, which may be calculated directly from excess mole fractions measured according to

$\frac{C_{i}}{C_{\mathrm{T}}}=\frac{\Delta[i]}{\sum_{j=1}^{\mathrm{n}}\left(\mathrm{NC}_{j} \times \Delta[j]\right)}$,

where $\Delta[i]$ and $\Delta[j]$ are the excess mole fractions of species $i$ and $j$ respectively (defined as the mole fraction, e.g. [i] measured in the smoke, minus the mean background mole fraction measured before the fire $\left.[i]_{\mathrm{bkgnd}}\right), \mathrm{NC}_{j}$ is the number of carbon atoms in compound $j$ and the sum is of all carbon-containing species emitted by the fire. Only those carbonaceous species retrieved in this work $\left(\mathrm{CO}_{2}, \mathrm{CO}, \mathrm{CH}_{4}\right.$, $\mathrm{C}_{2} \mathrm{H}_{4}, \mathrm{H}_{2} \mathrm{CO}, \mathrm{CH}_{3} \mathrm{OH}, \mathrm{HCOOH}$ and $\mathrm{CH}_{3} \mathrm{COOH}$ ) have been included in the emission factor calculations. While these do not represent all of the carbon-containing species emitted by a fire, they account for the vast majority of carbon emissions $(\sim>98 \%)$. Most of the carbon emitted by biomass burning is in the form of $\mathrm{CO}_{2}$ and $\mathrm{CO}(90-95 \%)$, with the remainder as $\mathrm{CH}_{4}$ or other volatile organic carbon compounds and particulate matter (Akagi et al., 2011). Use of only those carbonaceous species detected by FTIR spectrometry in this mass balance equation has been estimated to artificially inflate the emission factors by $1-2 \%$ (Yokelson et al., 2007).

$C_{i} / C_{\mathrm{T}}$ may also be calculated using emission ratios with respect to a reference species (usually $\mathrm{CO}_{2}$ or $\mathrm{CO}$ ) via

$$
\frac{C_{i}}{C_{\mathrm{T}}}=\frac{\mathrm{ER}_{i / \mathrm{CO}_{2}}}{\sum_{j=1}^{\mathrm{n}} \mathrm{NC}_{j} \times \mathrm{ER}_{j} / \mathrm{CO}_{2}},
$$


where $\mathrm{ER}_{i / y}$ is the emission ratio of species $i$ to the reference species $y$, given by

$\mathrm{ER}_{i / y}=\frac{\Delta[i]}{\Delta[y]}=\frac{[i]-[i]_{\mathrm{bkgnd}}}{[y]-[y]_{\mathrm{bkgnd}}}$,

where $\Delta[i]$ is the excess mole fraction of species $i$. (Note that when the measurements are made downwind of the fire in aged smoke, then these same ratios are commonly referred to as "enhancement ratios", to highlight the fact that chemical and physical processing may have altered the ratio of species from that which was originally emitted from the fire.) Deriving the emission ratios via the gradient of the linear best fit to a plot of the abundance of species $i$ against the abundance of reference species $y$, removes the requirement for accurate knowledge of the background mole fractions, yet introduces an insignificant degree of error (Wooster et al., 2011).

The emission factor for a particular species may then be calculated via

$\mathrm{EF}_{i}=\mathrm{ER}_{i / y} \times \frac{\mathrm{MW}_{i}}{\mathrm{MW}_{y}} \times \mathrm{EF}_{y}$,

where $\mathrm{EF}_{i}$ is the emission factor of species $i\left(\mathrm{~g} \mathrm{~kg}^{-1}\right), \mathrm{MM}_{i}$ and $\mathrm{MM}_{y}$ are the molecular weights of species $i$ and species $y$ respectively, and $\mathrm{EF}_{y}$ is the emission factor of the reference species $y$.

Since a mole fraction for each of the gases is retrieved from every spectrum recorded during the fire, it is possible to calculate a separate emission factor for each gas from every spectrum. However, emission factors of some gases may change as the fire develops depending upon the combustion efficiency of the material being burned. The combustion efficiency is defined as the proportion of total carbon emitted as $\mathrm{CO}_{2}$ and is now commonly approximated to a modified combustion efficiency (MCE) given by (Hao and Ward, 1993; Yokelson et al., 1996)

$\mathrm{MCE}=\frac{\Delta\left[\mathrm{CO}_{2}\right]}{\Delta\left[\mathrm{CO}_{2}\right]+\Delta[\mathrm{CO}]}$.

When the fire is dominated by flaming combustion, the combustion efficiency is high. It decreases as smouldering combustion becomes more dominant.

\subsection{Sampling geometries and potential biases}

Ideally, sampling techniques should capture a representative amount of flaming and smouldering combustion so that the measurements are representative of the fire as a whole. In a laboratory fire it is possible to ensure that all the emissions are captured and (if the flow rate is kept constant) be sure that measurements sampled truly represent the fire as a whole (Burling et al., 2010). In the field, ground-based in situ measurements are likely to be biased towards the smouldering stage of burning since flaming emissions are transported rapidly to higher altitudes via convection. Aircraftbased measurements capture both flaming and smouldering emissions lofted during the initial stages of the fire but may underestimate residual smouldering emissions. Since aircraft sampling captures smoke predominantly from the intense burning that consumes the majority of the fuel in forest fires (Akagi et al., 2014), it is more likely to closely resemble a true representative sample than a ground-level measurement. For fires that are dominated by smouldering combustion (e.g. peat fires), a ground-level sampling geometry would be superior.

In this study, the spectrometer and retro-reflectors were either placed downwind of the fire so that the wind would blow smoke into the measurement path (e.g. at Gibberagong and Abaroo Creek burns), across an area of burning forest (e.g. Max Allen Drive and Gulguer Nature Reserve) or immediately leeward of a steep escarpment (Alfords Point). These measurement geometries that sampled across the burning area were chosen so both flaming and smouldering emissions would pass through the line of sight. Nevertheless, this does not ensure a representative sample because the flaming emissions may be moving past the line of sight faster than smouldering emissions as they are driven upwards by convective forces. So for this study, we can postulate a probable bias towards the smouldering stages of combustion that is less pronounced that for an in situ ground-based measurement.

Different sampling biases are likely to result in different fire-averaged MCE values. Thus we can also predict that our fire-averaged MCE values are likely to lie below those typical for aircraft-based measurements (which are probably biased to flaming emissions and high MCE) and above those typical for ground-based in situ measurements (which are biased to smouldering emissions and low MCE). Although we can theorise about a potential sampling bias towards lower MCE values in our measurements, we have no mechanism to confirm this or to estimate its magnitude. For this reason, our measured sample is actually our best estimate of the overall fire emissions characteristics. When choosing how to combine all the measurements to estimate fire-averaged values, care must be taken not to introduce any further potential biases.

\subsection{Obtaining best estimates for fire-averaged emission factors}

One consequence of the fact that many emission factors change with combustion efficiency as the fire develops is that a measurement made at one stage of the fire may not be representative of the fire as a whole. There are a number of different ways in which whole-fire emissions estimates can be made, each with its own advantages and disadvantages, and these are outlined below:

1. Arithmetic mean: the simplest method is to calculate separate emission factors for each spectrum independently and to take a simple arithmetic mean. The problem with this approach is that it fails to account for 
the larger rate of biomass consumption during flaming combustion (Akagi et al., 2011). Thus, weighting all the spectra equally will result in an unwanted dependence on the relative time spent measuring during flaming and smouldering combustion. Since flaming combustion is relatively quick, this will bias the estimated fireaveraged emission factors towards smouldering emissions compared to the true overall emissions.

2. Regression to $\mathrm{CO}_{2}$ : a different method is to calculate emission ratios to $\mathrm{CO}_{2}$ for each species from the relevant regressions. Emission factors may then be calculated using Eqs. (1) and (3) that use the data from all spectra together. This is conceptually straightforward and has the advantage that the regression process lends more weight to points with larger enhancements (thereby weighting the spectra towards flaming combustion). The use of regressions to determine emission ratios also removes the need for accurate knowledge of background mole fractions of the trace gases. The difficulty with this method is that it relies on a regression line that can lie far from most points (between two distinct correlation lines that represent the emissions due to flaming and smouldering combustion), as illustrated in the top left-hand panel of Fig. 4. The calculated emission factors give greater weight to the flaming combustion than a simple arithmetic mean, but this weighting is not necessarily directly related to the amount of biomass that is consumed.

3. Separate flaming and smouldering via MCE: one way of accounting for strongly varying emission factors (calculated from individual spectra) as the fire progresses is to divide the results into those with MCE values typical of flaming (>90\%) and those with MCE values typical of smouldering $(<90 \%)$ and to present two separate emission factors (Lobert and Scharffe, 1991; Yokelson et al., 1996). In some previous studies, fire radiative power measurements have been made simultaneously with the measurement of emission factors and subsequently used to weight the relative contribution of flaming-dominated emissions and smouldering-dominated emissions from the fire as a whole. For example, Wooster et al. (2011) used the fire radiative power method in a southern African savanna and concluded that most of the fuel was consumed in the flaming-dominated stages, where cumulative fire radiative power was by far the greatest, so much so that fire-averaged emission factors were close to those measured at high MCE alone. In the absence of fire radiative power measurements, the issue of what proportion of flaming and smouldering combustion occurred in the fire as a whole may be left unanswered. Without an estimate of the relative amounts of fuel consumed within these MCE ranges, an estimate of the whole-fire emission factor cannot be made.
4. Summation method: a good way to ensure that the fireaveraged emission factor correctly weights each spectrum to the total biomass consumed is to calculate the total excess amounts of each gas detected by summing the excess amounts from each spectrum. The emission factors may then be calculated for the whole fire via Eqs. (1) and (2). This method has the significant advantage that it correctly weights each spectrum by the proportion of the total sampled excess carbonaceous species measured, with the only drawback being that it relies on accurate knowledge of background mole fractions.

5. Emission ratio to reference gas: emission factors may also be calculated via Eq. (5) using the measured emission ratio of the gas of interest with respect to a reference species (usually $\mathrm{CO}$ or $\mathrm{CO}_{2}$ ). Using the gradient of a regression line between the target gas and the reference gas will often yield the emission ratio with very low uncertainty, which is a significant advantage of this method. This method is sometimes used with an assumed value for the emission factor of the reference species (usually taken from a previous study or mean literature value for the ecosystem) which can introduce large extra uncertainties. However in this case, the emission factors of $\mathrm{CO}_{2}$ and $\mathrm{CO}$ can be derived directly from the measurements and so no such disadvantage is present.

In this study, we have chosen to use a combination of methods 4 and 5 above to calculate whole-fire emission factors. We have used the whole-fire summation method to obtain our best estimate for the emission factors of $\mathrm{CO}_{2}$ and $\mathrm{CO}$, using the background mole fraction values for these gases measured before ignition of the fires (which can be measured relatively easily). For all other gases (where the background values are often closer to the quantitation limits of the measurement technique), we have used emission ratios via Eq. (5) and the emission factors for $\mathrm{CO}_{2}$ and $\mathrm{CO}$ calculated for the fire via the summation method. This produces lower uncertainties than using the summation method for all gases because it does not rely on poorly defined background values for many of the trace gases. The reference species used for each of the emission factor calculations was chosen based upon which species $\left(\mathrm{CO}\right.$ or $\left.\mathrm{CO}_{2}\right)$ was more strongly correlated to the particular trace gas $i ; \mathrm{C}_{2} \mathrm{H}_{4}, \mathrm{H}_{2} \mathrm{CO}$ and $\mathrm{N}_{2} \mathrm{O}$ were most strongly correlated to $\mathrm{CO}_{2}$ whereas all other gases were most strongly correlated to $\mathrm{CO}$.

\subsection{Estimation of measurement uncertainties}

There are a number of difficulties in obtaining a good estimate of measurement uncertainty for the type of measurements described in this paper. Probably the most significant of these is the fact that it is not possible to know whether or not the measurements actually recorded are a 

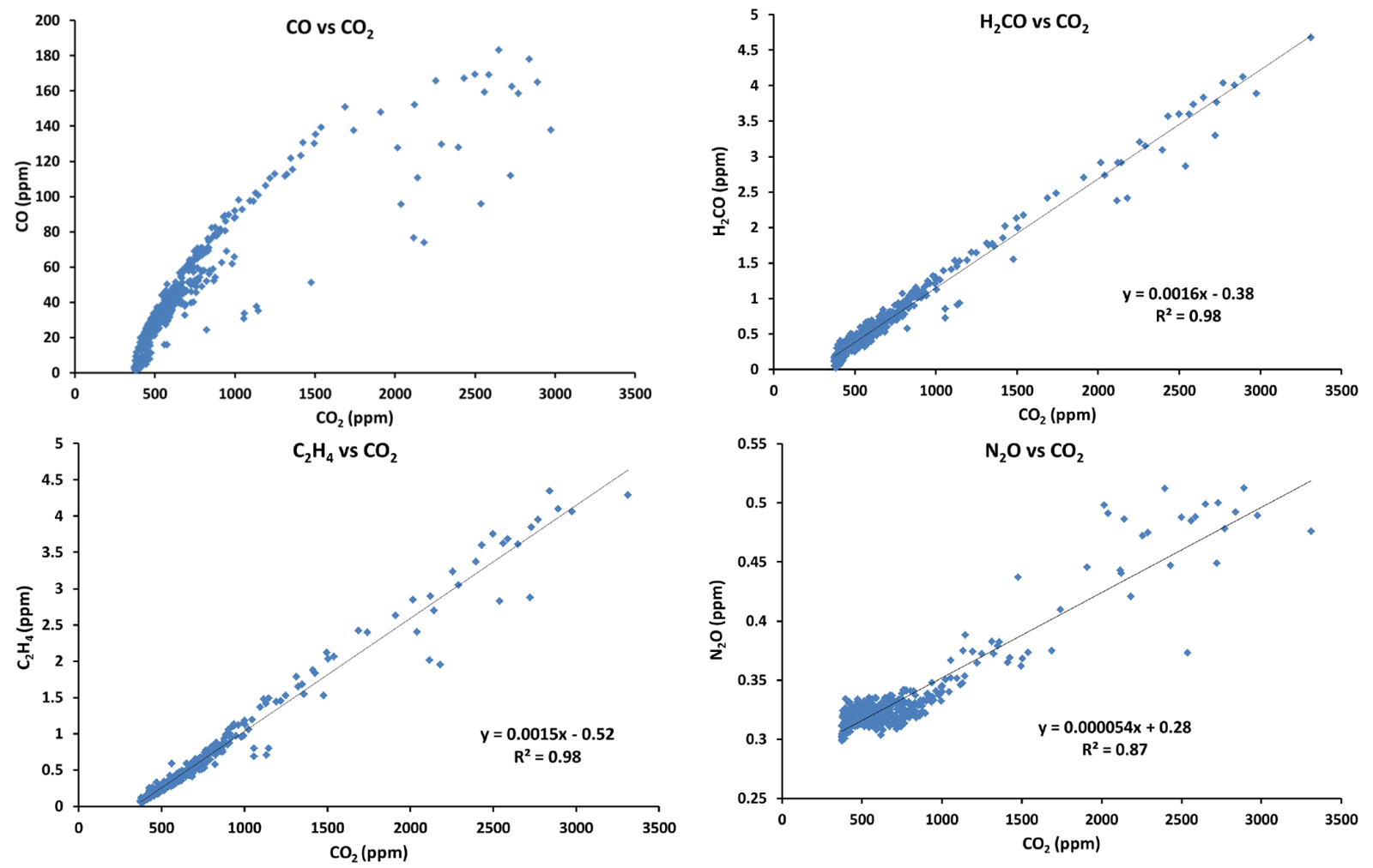

Figure 4. Example correlation plots with respect to $\mathrm{CO}_{2}$ from the Alfords Point burn. Upper left-hand panel is $\mathrm{CO}_{\text {vs. }} \mathrm{CO}_{2}$; upper right-hand panel is $\mathrm{H}_{2} \mathrm{CO}$ vs. $\mathrm{CO}_{2}$; lower left-hand panel is $\mathrm{C}_{2} \mathrm{H}_{4}$ vs. $\mathrm{CO}_{2}$ and lower right-hand panel is $\mathrm{N}_{2} \mathrm{O}$ vs. $\mathrm{CO}_{2}$.

good representative sample of the fire as a whole (see Sect. 4.2). Another issue is that the measurements are sensitive to the assumed temperature in the retrieval algorithm. This presents a difficulty because the real temperature may vary substantially along the line of sight of the measurement, especially when measuring through flames. An error in the assumed temperature has two effects on the retrieved concentration. The first is that it impacts on the density and hence the concentration of the gases. This density effect actually cancels out in the calculation of emission factors because it has no impact on the fraction of carbon emitted as each trace gas species. The second temperature effect is on the line strengths of individual absorption lines and the impact of this will be different for different spectroscopic windows used. Trace gases absorbing at a large range of different temperatures or a large error in the assumed temperature will also result in a poor fit and thus also impact the spectral fitting error. Despite these difficulties, it is a useful exercise to try to estimate the likely magnitude of the measurement uncertainties. In Appendix B we work through our methods for estimating measurement uncertainties, starting with the emission factors for $\mathrm{CO}_{2}$ and $\mathrm{CO}$. Uncertainties are also estimated for emission ratios by combining uncertainties in temperature, spectral fitting (including signal-to-noise ratio), HITRAN line parameters and the gradient of the emission ratio plots. Finally, emission factor uncertainties are determined by combining in quadrature uncertainties in the emission ratios and in the emission factors of the reference gas $\mathrm{CO}$ or $\mathrm{CO}_{2}$. See Appendix B for further details.

\section{Results}

\subsection{Emission ratios to $\mathrm{CO}$ and $\mathrm{CO}_{2}$}

Emission factors for $\mathrm{CO}_{2}$ and $\mathrm{CO}$ were calculated for all fires by summing the excess amounts of $\mathrm{CO}_{2}, \mathrm{CO}, \mathrm{CH}_{4}, \mathrm{C}_{2} \mathrm{H}_{4}$, $\mathrm{H}_{2} \mathrm{CO}, \mathrm{HCOOH}$ and $\mathrm{CH}_{3} \mathrm{COOH}$ from all spectra to yield total excess amounts $\Delta\left[\mathrm{CO}_{2}\right], \Delta[\mathrm{CO}], \Delta\left[\mathrm{CH}_{4}\right], \Delta\left[\mathrm{C}_{2} \mathrm{H}_{4}\right]$, $\Delta\left[\mathrm{H}_{2} \mathrm{CO}\right], \Delta[\mathrm{HCOOH}]$ and $\Delta\left[\mathrm{CH}_{3} \mathrm{COOH}\right]$ from each fire (assuming a carbon content " $F_{\mathrm{C}}$ " of $50 \%$ ) and applying Eqs. (1) and (2).

Emission factors for all other trace gases were calculated using the emission ratio to either $\mathrm{CO}$ or $\mathrm{CO}_{2}$, depending upon which showed the stronger correlation. The reason to switch methods is that the uncertainties in background concentrations have little impact on the emission factors of $\mathrm{CO}_{2}$ and $\mathrm{CO}$ but this can become a large uncertainty for other gases. Knowledge of background concentrations is not required if emission factors are calculated via emission ratios (using the gradients of the correlation plots). Example correlation plots from the Alfords Point burn for gases that were 

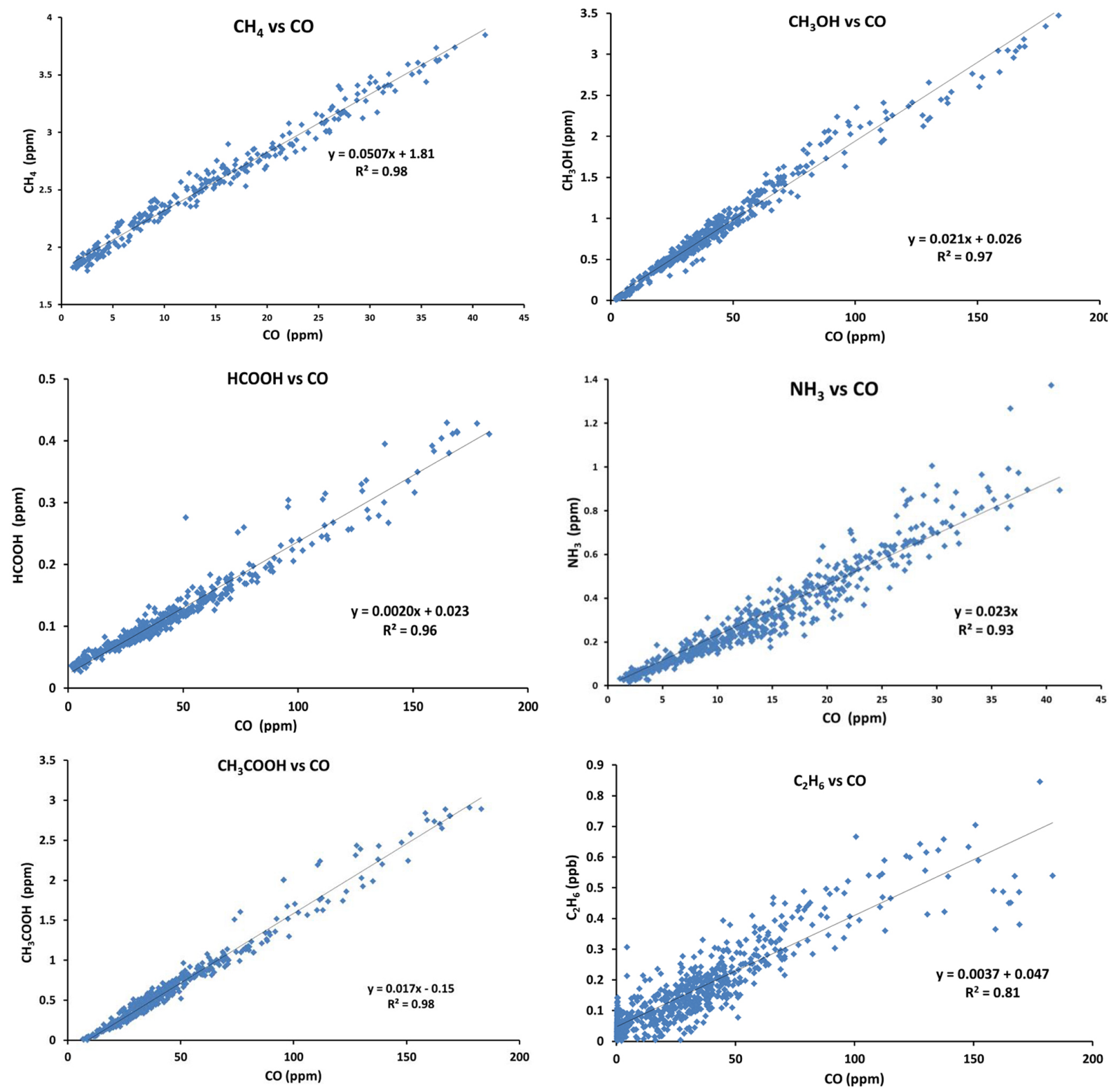

Figure 5. Example correlation plots with respect to $\mathrm{CO}$ taken from Alfords Point or Abaroo. Upper left-hand panel is $\mathrm{CH}_{4}$ vs. $\mathrm{CO}$; upper right-hand panel is $\mathrm{CH}_{3} \mathrm{OH}$ vs. $\mathrm{CO}$; middle left-hand panel is $\mathrm{HCOOH}$ vs. $\mathrm{CO}$; middle right-hand panel is $\mathrm{NH}_{3}$ vs. $\mathrm{CO}$; lower left-hand panel is $\mathrm{CH}_{3} \mathrm{COOH}$ vs. $\mathrm{CO}$ and lower right-hand panel is $\mathrm{C}_{2} \mathrm{H}_{6}$ vs. $\mathrm{CO}$.

most strongly correlated to $\mathrm{CO}_{2}\left(\mathrm{C}_{2} \mathrm{H}_{4}, \mathrm{H}_{2} \mathrm{CO}\right.$ and $\left.\mathrm{N}_{2} \mathrm{O}\right)$ are shown in Fig. 4 along with the $\mathrm{CO}$ versus $\mathrm{CO}_{2}$ correlation plot.

All other gases $\left(\mathrm{CH}_{4}, \mathrm{NH}_{3}, \mathrm{CH}_{3} \mathrm{OH}, \mathrm{CH}_{3} \mathrm{COOH}\right.$, $\mathrm{HCOOH}$ and $\mathrm{C}_{2} \mathrm{H}_{6}$, ) showed stronger correlation to CO. Example correlation plots are shown in Fig. 5, from either Alfords Point or Abaroo burns. Emission ratios were derived from the gradients of these correlation plots using generalised least squares regression. (This is the best fit to the points that minimises deviations from the line of fit in both $x$ and $y$ axes and is weighted by the uncertainties in both $x$ and $y$ ).

Table 3 shows the results of the generalised least squares regression analysis, with the emission ratio and its uncertainty given. Also shown is the square of the correlation coefficient to a simple linear regression $\left(R^{2}\right)$. This is also provided because it is a more commonly understood measure of the strength of the correlation.

Note that $\mathrm{N}_{2} \mathrm{O}$ to $\mathrm{CO}_{2}$ emission ratios could only be determined from the Gulguer Nature Reserve and Alfords Point burns where spectra with very large enhancements of trace 
Table 3. Results of the generalised least squares regression analysis, with the emission ratio (ER) and its uncertainty ( $S_{\mathrm{ER}}$ ). Also shown is $R^{2}$, the square of the correlation coefficient to a simple linear regression. The arithmetic mean and standard deviation of the emission ratios measured at all of the fires are given. In addition the modified combustion efficiency (MCE) values calculated via the summation method for each fire are given.

\begin{tabular}{|c|c|c|c|c|c|c|c|c|c|c|c|c|}
\hline & Lane Cove & $R^{2}$ & Turramurra & $R^{2}$ & Abaroo Creek & $R^{2}$ & Gulguer & $R^{2}$ & Alfords Point & $R^{2}$ & Mean & Std dev. \\
\hline $\mathrm{C}_{2} \mathrm{H}_{4} / \mathrm{CO}_{2}$ & $0.0016 \pm 0.0003$ & 0.83 & $0.0010 \pm 0.0002$ & 0.96 & $0.0010 \pm 0.0002$ & 0.97 & $0.0010 \pm 0.0002$ & 0.95 & $0.0015 \pm 00003$ & 0.98 & 0.0012 & 0.0003 \\
\hline $\mathrm{H}_{2} \mathrm{CO} / \mathrm{CO}_{2}$ & $0.0022 \pm 0.0003$ & 0.73 & $0.0013 \pm 0.0002$ & 0.89 & $0.0012 \pm 0.0002$ & 0.90 & $0.0015 \pm 0.0002$ & 0.91 & $0.0016 \pm 0.0002$ & 0.98 & 0.0016 & 0.0004 \\
\hline $\mathrm{N}_{2} \mathrm{O} / \mathrm{CO}_{2}$ & & & & & & & $0.00013 \pm 0.00002$ & 0.81 & $0.000054 \pm 0.000008$ & 0.87 & 0.00009 & 0.00005 \\
\hline $\mathrm{CH}_{4} / \mathrm{CO}$ & $0.062 \pm 0.005$ & 0.91 & $0.048 \pm 0.004$ & 0.98 & $0.046 \pm 0.003$ & 0.98 & $0.041 \pm 0.003$ & 0.98 & $0.063 \pm 0.005^{*}$ & 0.97 & 0.052 & 0.010 \\
\hline $\mathrm{CH}_{3} \mathrm{OH} / \mathrm{CO}$ & $0.026 \pm 0.002$ & 0.90 & $0.013 \pm 0.001$ & 0.95 & $0.013 \pm 0.001$ & 0.93 & $0.012 \pm 0.001$ & 0.94 & $0.021 \pm 0.002$ & 0.97 & 0.017 & 0.006 \\
\hline $\mathrm{CH}_{3} \mathrm{COOH} / \mathrm{CO}$ & $0.019 \pm 0.003$ & 0.86 & $0.012 \pm 0.002$ & 0.85 & $0.012 \pm 0.002$ & 0.97 & $0.015 \pm 0.002$ & 0.93 & $0.017 \pm 0.002$ & 0.98 & 0.015 & 0.003 \\
\hline $\mathrm{NH}_{3} / \mathrm{CO}$ & $0.026 \pm 0.004$ & 0.90 & $0.015 \pm 0.002$ & 0.85 & $0.023 \pm 0.003$ & 0.93 & $0.012 \pm 0.002$ & 0.91 & $0.030 \pm 0.004^{*}$ & 0.93 & 0.021 & 0.008 \\
\hline $\mathrm{HCOOH} / \mathrm{CO}$ & $0.0033 \pm 0.0006$ & 0.80 & $0.0015 \pm 0.0003$ & 0.69 & $0.0017 \pm 0.0003$ & 0.88 & $0.0020 \pm 0.0004$ & 0.92 & $0.0020 \pm 0.0004$ & 0.96 & 0.0021 & 0.0007 \\
\hline $\mathrm{C}_{2} \mathrm{H}_{6} / \mathrm{CO}$ & & & & & & & & & $0.0037 \pm 0.0010$ & 0.81 & (0.0037) & \\
\hline MCE & 0.88 & & 0.91 & & 0.91 & & 0.90 & & 0.88 & & & \\
\hline
\end{tabular}

gases were measured $\left(\mathrm{CO}_{2}\right.$ in excess of $1000 \mathrm{ppm}$ and $\mathrm{CO}$ in excess of $100 \mathrm{ppm}$ ). This is because $\mathrm{N}_{2} \mathrm{O}$ sits under the $\mathrm{CO}$ and $\mathrm{CO}_{2}$ bands and thus the emission ratio is difficult to measure unless the enhancements are very large. This is also true for $\mathrm{C}_{2} \mathrm{H}_{6}$ because its spectral absorption features are weak. Thus, we only managed to determine $\mathrm{C}_{2} \mathrm{H}_{6}$ to $\mathrm{CO}$ emission ratio for the Alfords Point burn.

\subsection{Comparison of emission ratios to previous studies}

Most trace gases exhibit very strong correlations with either $\mathrm{CO}$ or $\mathrm{CO}_{2}$, as can be seen by the large $R^{2}$ values given in Table 3 . Also shown in Table 3 are the mean and standard deviation values for the emission ratios from all the fires sampled. For all gases, the natural variability (as seen in the standard deviation of emission ratios measured at different fires) exceeds the measurement uncertainty for the emission ratio at an individual fire.

This study provides the first direct measurements of emission factors for many gases from Australian forest fires. In the absence of previous measurements of emission factors, it is interesting to compare our measured emission ratios with enhancement ratios (measured in aged smoke) from Australian forest fires reported in the literature.

Mean $\mathrm{CH}_{3} \mathrm{OH}$ to $\mathrm{CO}$ ratios from this study $(0.017 \pm 0.006)$ are in excellent agreement with the only previous reported emission ratio from this ecosystem of $0.019 \pm 0.001$ using ground-based solar remote sensing Fourier transform spectrometry (Paton-Walsh et al., 2008). Mean $\mathrm{NH}_{3}$ to $\mathrm{CO}$ and $\mathrm{C}_{2} \mathrm{H}_{6}$ to $\mathrm{CO}$ ratios from this study $(0.021 \pm 0.008)$ and $(0.0037)$ respectively are higher than those reported by Paton-Walsh et al. (2005) (also using ground-based solar remote sensing Fourier transform spectrometry) of $0.0095 \pm 0.0035$ and $0.0023 \pm 0.0005$. The discrepancy in $\mathrm{NH}_{3}$ values is likely due to chemical loss in the aged smoke sampled in the earlier studies (Akagi et al., 2012; Goode et al., 2000). Our single $\mathrm{C}_{2} \mathrm{H}_{6}$ to $\mathrm{CO}$ emission ratio is $\sim 30 \%$ higher than the value reported by Paton-Walsh et al. (2005) but our estimated measurement uncertainty is $27 \%$, and with only a single value it is difficult to know whether this is due to natural variability or measurement biases.

The 10-times-lower $\mathrm{HCOOH}$ to $\mathrm{CO}$ ratio measured in this study $(0.0021 \pm 0.0008)$ than the enhancement ratio measured by Paton-Walsh et al. (2005) of $0.021 \pm 0.010$ in smoke aged a few hours, is predominantly due to $\mathrm{HCOOH}$ being chemically produced in the smoke plume as it ages (Goode et al., 2000; Yokelson et al., 2009). Another difference arises from the fact that the Paton-Walsh et al. (2005) emission ratio needs to be reduced by approximately $50 \%$ to correct for errors in the old HITRAN line parameters (Rothman et al., 2009). Our emission ratio from this study is in much better agreement with the Alvarado et al. (2011) measurement of $0.0031 \pm 0.0021$ for Canadian forest fires using the satellite-based sensor TES. Our calculated emission factor for $\mathrm{HCOOH}$ of $0.4 \pm 0.2 \mathrm{~g} \mathrm{~kg}^{-1}$ dry fuel consumed falls within the expected range for measurements made in fresh smoke and is also in good agreement with the Akagi et al. (2014) measurement of $0.36 \pm 0.04 \mathrm{~g} \mathrm{~kg}^{-1}$ for pine understorey burns in South Carolina, USA measured by open-path FTIR spectrometry.

We may also compare the enhancement ratios with respect to $\mathrm{CO}$ for $\mathrm{C}_{2} \mathrm{H}_{4}$ and $\mathrm{H}_{2} \mathrm{CO}$ reported by Paton-Walsh et al. (2005) and Young and Paton-Walsh (2011) from wildfires in Australian forests with our emission ratios with respect to $\mathrm{CO}_{2}$ by assuming the mean emission factors for $\mathrm{CO}_{2}$ and $\mathrm{CO}$ measured in this study. (This produces a multiplication factor of 0.114 to convert an emission ratio with respect to $\mathrm{CO}$ to an equivalent emission ratio with respect to $\mathrm{CO}_{2}$.) Thus the $\mathrm{C}_{2} \mathrm{H}_{4}$ to $\mathrm{CO}$ enhancement ratio reported by Paton-Walsh et al. (2005) of $0.0057 \pm 0.0027$ is equivalent to a $\mathrm{C}_{2} \mathrm{H}_{4}$ to $\mathrm{CO}_{2}$ ratio of $0.00065 \pm 0.00031$ or approximately half our measured value of $0.0012 \pm 0.0003$. Akagi et al. (2012) also report a rapid drop in $\mathrm{C}_{2} \mathrm{H}_{4}$ to $\mathrm{CO}$ ratios as the smoke ages.

Similarly, the $\mathrm{H}_{2} \mathrm{CO}$ to $\mathrm{CO}$ enhancement ratios of $0.023 \pm 0.007$ and $0.016 \pm 0.004$ reported by Paton-Walsh et al. (2005) and Young and Paton-Walsh (2011) respectively are equivalent to a $\mathrm{H}_{2} \mathrm{CO}$ to $\mathrm{CO}_{2}$ ratio of $0.0026 \pm 0.0008$ 
and $0.0018 \pm 0.0005$, in broad agreement with our mean measured value of $0.0016 \pm 0.0004$

\subsection{New emission factors for Australian temperate forest fires}

Emission factors for $\mathrm{CO}_{2}$ and $\mathrm{CO}$ were calculated by the summation method as described in Sect. 4.3. The results are shown in Table 4 for each individual fire along with the mean and standard deviation from all of the fires sampled. Emission factors for all other gases were calculated (via Eq. 5) from the $\mathrm{CO}_{2}$ and $\mathrm{CO}$ emission factors for the relevant fires and the emission ratios in Table 3 . The uncertainties were calculated by combining in quadrature the uncertainties in the emission ratios with the uncertainty of the emission factor of the reference gas $\left(\mathrm{CO}\right.$ or $\left.\mathrm{CO}_{2}\right)$ as outlined in Appendix B.

For $\mathrm{CO}_{2}$ and $\mathrm{CO}$ emission factors, the measurement uncertainty (which is dominated by the uncertainty in the fractional carbon content of the fuel) exceeds the variability between fires. For all other gases, the standard deviation of the mean is greater than the measurement uncertainty for emission factors from individual fires, indicating large true natural variability in the emissions of these gases. The most natural variability is seen for $\mathrm{CH}_{3} \mathrm{OH}, \mathrm{HCOOH}$ and $\mathrm{NH}_{3}$, with $\mathrm{CH}_{4}$ and $\mathrm{C}_{2} \mathrm{H}_{4}$ displaying less variability and $\mathrm{H}_{2} \mathrm{CO}$ the least variability in emission factors from the fires that we sampled. The larger of these two numbers (measurement uncertainty or one-sigma standard deviation) is taken as the uncertainty in the mean emission factor for each trace gas.

\subsection{Discussion of the applicability of new emission factors in this study}

For many trace gases, the new emission factors presented here are the first provided in the literature for Australian forest fires. The predominance of eucalypt species mean that the fuels in this ecosystem may vary substantially from generic "extratropical forest" biomes. Nevertheless, there is still great uncertainty in the factors that drive the large variability in emission factors and thus not all models are driven mainly by regional-scale emissions factors (Akagi et al., 2013; van Leeuwen et al., 2013). The emission factors presented here are from a relatively small number of hazard reduction burns all within $100 \mathrm{~km}$ of each other. Hazard reduction burns should burn with less intensity then the wildfires that they are designed to inhibit, and hence lower MCE values and different emission factors might be expected. For these reasons, the emission factors measured during this study may not necessarily be the most applicable for those wanting to model atmospheric impacts of large-scale wildfires in Australia. Nevertheless, it is interesting to note that several trace gases had emission ratios that were in agreement with those measured in remotely sensed smoke plumes from wildfires. Whether the emission factors for hazard re- duction burning and for wildfires are significantly different is still an unanswered question.

The fire-averaged MCE values that we determined for each fire are one piece of evidence that we can use as an indication of how representative our measurements are likely to be of other fires in this ecosystem. MCE values in this study ranged from a minimum of 0.88 at the Lane Cove burn to a maximum of 0.91 at the Abaroo Creek burn. This is a surprisingly small spread in MCE values given the significantly different measurement geometries. These MCE values are comparable to those calculated from the mean emission factors for $\mathrm{CO}_{2}$ and $\mathrm{CO}$ presented by Akagi et al. (2011) for temperate forests of 0.92 and for extratropical forests of 0.89 (where extratropical forests represent a weighted average of boreal and temperate forests based on GFED3 biomass consumption estimates; van der Werf et al., 2010). Mean MCE values reported for laboratory burns by Burling et al. (2010) are slightly higher at $0.93 \pm 0.04$, but Yokelson et al. (2013) conclude that laboratory fires most probably yield higher MCE values due to typically lower fuel moisture content and the lack of wind to sustain smouldering combustion.

Thus MCE values that we obtain in this study are similar to what we would expect from a fire-averaged hazard reduction burn. This lends confidence that open-path FTS methodology is a reasonably sound technique for measuring a representative sample, as long as care is taken to ensure that the line of sight chosen captures flaming emissions as well as smouldering and the results are weighted to the total enhancements measured.

Despite the caveats of a small sample size and small geographic spread of sites sampled, the emission factors provided here are the first for many trace gases from Australian forest fires. Therefore, for those wishing to model emissions using geographical regions, we recommend the use of our mean emission factors to characterise the emissions from Australian forest fires in fire inventories.

\subsection{Comparison of emission factors to previous studies}

We can compare our emission factors for $\mathrm{CO}_{2}, \mathrm{CO}$ and $\mathrm{CH}_{4}$ to those measured previously by Hurst et al. (1996), who quoted emission factors in terms of fraction of fuel carbon burned (i.e $C_{i} / C_{\mathrm{T}}$ ). If we make the same assumption as we did in this study (that the fractional carbon content is $50 \%$ ) and apply this to their quoted values, we get equivalent emission factors of $1560 \mathrm{~g} \mathrm{CO}_{2} \mathrm{~kg}^{-1}$ of dry fuel consumed, $106 \mathrm{~g} \mathrm{CO} \mathrm{kg}^{-1}$ of dry fuel consumed and $3.6 \mathrm{~g} \mathrm{CH}_{4} \mathrm{~kg}^{-1}$ of dry fuel consumed. Our estimates give a slightly larger amount of total carbon emerging as both $\mathrm{CO}_{2}$ and $\mathrm{CO}$ than that estimated by Hurst et al. (1996) and a very similar value for $\mathrm{CH}_{4}$. The small differences in emission factors for $\mathrm{CO}_{2}$ and $\mathrm{CO}$ can be fully accounted for in the different assumptions made about carbon emissions that were not measured - i.e. in this study we assumed that the total measured carbon emissions were approximately equal to the total emitted 
Table 4. Emission factors $\left(\mathrm{EF}_{\mathrm{gas}}\right)$ in $\mathrm{g} \mathrm{kg}^{-1}$ and uncertainties for each fire along with the mean and standard deviation of the emission factors from all of the fires sampled. The measurement uncertainty in the mean result is shown in parentheses.

\begin{tabular}{|c|c|c|c|c|c|c|c|c|}
\hline & $\begin{array}{l}\text { Lane } \\
\text { Cove }\end{array}$ & Turramurra & $\begin{array}{c}\text { Abaroo } \\
\text { Creek }\end{array}$ & $\begin{array}{l}\text { Gulguer } \\
\text { Nature } \\
\text { Reserve }\end{array}$ & $\begin{array}{c}\text { Alfords } \\
\text { Point }\end{array}$ & $\begin{array}{l}\text { Mean } \pm \text { Std dev. } \\
\text { (Uncertainty) } \\
\text { from this study }\end{array}$ & $\begin{array}{c}\text { Akagi et al. (2011) } \\
\text { for temperate } \\
\text { forests }\end{array}$ & $\begin{array}{c}\text { Akagi et al. (2011) } \\
\text { for extratropical } \\
\text { forests }\end{array}$ \\
\hline $\mathrm{EF}_{\mathrm{CO}_{2}}$ & $1,580 \pm 160$ & $1,640 \pm 160$ & $1,650 \pm 170$ & $1,640 \pm 160$ & $1,590 \pm 160$ & $1,620 \pm 30(160)$ & $1637 \pm 71$ & $1509 \pm 98$ \\
\hline $\mathrm{EF}_{\mathrm{CO}}$ & $136 \pm 22$ & $106 \pm 17$ & $102 \pm 16$ & $112 \pm 18$ & $133 \pm 21$ & $118 \pm 16(19)$ & $89 \pm 32$ & $122 \pm 44$ \\
\hline $\mathrm{EF}_{\mathrm{CH}_{4}}$ & $4.8 \pm 0.9$ & $2.9 \pm 0.5$ & $2.7 \pm 0.4$ & $2.7 \pm 0.5$ & $4.8 \pm 0.9$ & $3.6 \pm 1.1(0.6)$ & $3.9 \pm 2.4$ & $5.7 \pm 3.2$ \\
\hline $\mathrm{EF}_{\mathrm{C}_{2} \mathrm{H}_{4}}$ & $1.6 \pm 0.3$ & $1.1 \pm 0.2$ & $1.1 \pm 0.2$ & $1.1 \pm 0.2$ & $1.5 \pm 0.3$ & $1.3 \pm 0.3(0.25)$ & $1.1 \pm 0.4$ & $1.4 \pm 0.4$ \\
\hline $\mathrm{EF}_{\mathrm{H}_{2} \mathrm{CO}}$ & $2.4 \pm 0.4$ & $1.5 \pm 0.3$ & $1.4 \pm 0.2$ & $1.7 \pm 0.3$ & $1.8 \pm 0.3$ & $1.7 \pm 0.4(0.3)$ & $2.3 \pm 1.1$ & $1.9 \pm 1.1$ \\
\hline $\mathrm{EF}_{\mathrm{CH}_{3} \mathrm{OH}}$ & $4.0 \pm 0.8$ & $1.6 \pm 0.3$ & $1.5 \pm 0.3$ & $1.6 \pm 0.3$ & $3.2 \pm 0.6$ & $2.4 \pm 1.2(0.4)$ & $1.9 \pm 1.4$ & $2.7 \pm 1.8$ \\
\hline $\mathrm{EF}_{\mathrm{CH}_{3} \mathrm{COOH}}$ & $5.5 \pm 1.2$ & $2.8 \pm 0.6$ & $2.6 \pm 0.6$ & $3.6 \pm 0.8$ & $4.8 \pm 1.0$ & $3.8 \pm 1.3(0.8)$ & $2.0 \pm 1.6$ & $4.1 \pm 3.0$ \\
\hline $\mathrm{EF}_{\mathrm{HCOOH}}$ & $0.7 \pm 0.2$ & $0.26 \pm .06$ & $0.29 \pm 0.07$ & $0.36 \pm 0.09$ & $0.43 \pm 0.11$ & $0.4 \pm 0.2(0.1)$ & $0.35 \pm 0.33$ & $0.54 \pm 0.47$ \\
\hline $\mathrm{EF}_{\mathrm{NH}_{3}}$ & $2.2 \pm 0.5$ & $1.0 \pm 0.2$ & $1.4 \pm 0.3$ & $0.8 \pm 0.2$ & $2.4 \pm 0.6$ & $1.6 \pm 0.6(0.4)$ & $0.78 \pm 0.82$ & $2.5 \pm 2.4$ \\
\hline $\mathrm{EF}_{\mathrm{N}_{2} \mathrm{O}}$ & & & & $0.21 \pm 0.04$ & $0.09 \pm 0.01$ & $0.15 \pm 0.09(0.03)$ & $0.16 \pm 0.21$ & $0.38 \pm 0.35$ \\
\hline $\mathrm{EF}_{\mathrm{C}_{2} \mathrm{H}_{6}}$ & & & & & $0.5 \pm 0.2$ & $0.5(0.2)$ & $1.1 \pm 0.7$ & $1.7 \pm 1.0$ \\
\hline
\end{tabular}

carbon, whilst Hurst et al. (1996) assumed $6 \%$ carbon emitted in ash.

There are no previously published emission factors for Australian temperate forest fires for any of the other gases measured in this study, but for comparison the mean values for temperate forest fires and extratropical fires in other parts of the world are given in the final columns of Table 4 (Akagi et al., 2011). Very large estimates of the natural variability for many trace gases are presented by Akagi et al. (2011) and consequently all our results overlap within the stated uncertainties and expected ranges. However, our emission factor for $\mathrm{CO}$ is quite a bit higher and closer to their estimated mean value for extratropical forests of $122 \pm 44 \mathrm{~g} \mathrm{~kg}^{-1}$ dry fuel consumed.

Also of note are higher emission factors for $\mathrm{CH}_{3} \mathrm{COOH}$ and $\mathrm{NH}_{3}$ (also more typical of extratropical forest estimates) and significantly lower $\mathrm{C}_{2} \mathrm{H}_{6}$ emissions as reported previously by Paton-Walsh et al. (2005).

\section{Summary and conclusions}

We present results from open-path FTIR measurements of emission factors for Australian temperate forest fires from five hazard reduction burns in New South Wales. A detailed description of the measurement set-up and analysis procedure is given, including spectral regions used for retrieving several trace gases from highly polluted smoky environments. Different methods for deriving best estimates for fire-averaged emission factors are presented and we conclude that, for our measurement geometry, it is best to use a wholefire integrated method (or "summation method") to derive emission factors for $\mathrm{CO}_{2}$ and $\mathrm{CO}$. For all other trace gases, we recommend that the emission factor is derived using the emission ratio to one of these reference gases $\left(\mathrm{CO}_{2}\right.$ or $\left.\mathrm{CO}\right)$, whichever gives the strongest correlation.
Despite possible sampling biases, the MCE values obtained lend confidence that open-path Fourier transform spectrometry is probably capable of capturing a reasonably representative sample of flaming and smouldering combustion when a suitable viewing geometry is available. Our sample size is quite small, with all the fires being hazard reduction burns from a relatively small geographic spread. Nevertheless, in the absence of any alternative measurements for many gases in this ecosystem, we recommend our mean emission factors for use in region-specific biomass burning inventories.

The recommended ecosystem-specific emission factors for Australian temperate forest fires (in grams of gas emitted per kilogram of dry fuel burned) are therefore

$1620 \pm 160 \mathrm{~g} \mathrm{~kg}^{-1}$ of $\mathrm{CO}_{2} ; 120 \pm 20 \mathrm{~g} \mathrm{~kg}^{-1}$ of $\mathrm{CO}$; $3.6 \pm 1.1 \mathrm{~g} \mathrm{~kg}^{-1}$ of $\mathrm{CH}_{4} ; \quad 1.3 \pm 0.3 \mathrm{~g} \mathrm{~kg}^{-1}$ of $\mathrm{C}_{2} \mathrm{H}_{4}$; $1.7 \pm 0.4 \mathrm{~g} \mathrm{~kg}^{-1}$ of $\mathrm{H}_{2} \mathrm{CO} ; 2.4 \pm 1.2 \mathrm{~g} \mathrm{~kg}^{-1}$ of $\mathrm{CH}_{3} \mathrm{OH}$; $3.8 \pm 1.3 \mathrm{~g} \mathrm{~kg}^{-1}$ of $\mathrm{CH}_{3} \mathrm{COOH} ; \quad 0.4 \pm 0.2 \mathrm{~g} \mathrm{~kg}^{-1}$ of $\mathrm{HCOOH} ; \quad 1.6 \pm 0.6 \mathrm{~g} \mathrm{~kg}^{-1}$ of $\mathrm{NH}_{3} ; \quad 0.15 \pm 0.09 \mathrm{~g} \mathrm{~kg}^{-1}$ of $\mathrm{N}_{2} \mathrm{O}$ and $0.5 \pm 0.2 \mathrm{~g} \mathrm{~kg}^{-1}$ of $\mathrm{C}_{2} \mathrm{H}_{6}$. 


\section{Appendix A: Details of spectral analysis}

\section{A1 Quantitative analysis of infrared spectra}

The MALT model requires environmental parameters (temperature and pressure) along with parameters that describe the spectrometer and the resulting instrument line shape in order to calculate the synthetic spectrum. Each of these instrument parameters may be fixed or fitted during the retrieval process. If an instrument parameter is fitted, then the initially assigned value is also adjusted (along with the trace gas mole fractions) such that the final value minimises the difference between the measured and simulated spectra.

In this study, the Bomem MB-100 Series FTIR spectrometer was modelled using a resolution of $0.96 \mathrm{~cm}^{-1}$ (fixed), a field of view of 22 milliradians (fixed), with a Hamming apodisation function applied to match the apodisation applied to the measured spectra. The spectrometer had a few imperfections that resulted in a non-ideal instrument line shape. An imperfect alignment causes a phase error and shifts the wave-number scale from the true line positions that are listed in the HITRAN database. The phase error was assigned an initial value of $-2^{\circ}$ and the wave-number shift assigned an initial value of $0.1 \mathrm{~cm}^{-1}$ and both these parameters were fitted during the retrieval. An empirical asymmetry function was applied to the MALT simulated spectra in order to replicate the actual instrument line shape better (in addition to fitting a phase error).

Imperfect alignment also causes a broadening of the line widths of absorbing gases. This additional broadening is described by an instrument parameter called the "effective apodisation". This is a trapezoidal apodisation function varying from zero (equivalent to a boxcar function for a perfectly aligned instrument) to a value of one (representing a triangular apodisation function). This parameter was fitted for the retrieval of some trace gases (to obtain the best possible fit) and fixed for others, particularly weak absorbers (in order to ensure a stable fit). Finally, in fitting the simulated spectrum to the measured spectrum, MALT can allow different degrees of freedom in fitting the continuum level (i.e. the intensity of radiation at each wave number with no absorption lines present). In most of the spectral regions used in this study, a second-order polynomial fit to the continuum level was used (allowing for some non-linear variation of the optical transmission across the wave-number range used).

\section{A2 Spectral region for fitting carbon dioxide and carbon monoxide}

Carbon dioxide exhibits strong infrared absorptions, even at ambient mole fractions. Unfortunately, the vibrationalrotational band for the asymmetric stretch of the main isotope of carbon dioxide $\left({ }^{12} \mathrm{CO}_{2}\right)$ is saturated at current background amounts $(\sim 394 \mathrm{ppm})$. This makes carbon dioxide surprisingly difficult to retrieve accurately from the type of infrared spectra recorded here. Many spectral regions were trialled during this study and these tests showed that a poorly chosen spectral region can introduce inaccuracies of up to $20 \%$. In the end, the region from 2080 to $2270 \mathrm{~cm}^{-1}$ was chosen for the retrieval of $\mathrm{CO}_{2}$ and $\mathrm{CO}$ from the spectra recorded through smoke at the hazard reduction burns. Nitrous oxide $\left(\mathrm{N}_{2} \mathrm{O}\right)$ and water $\left(\mathrm{H}_{2} \mathrm{O}\right)$ are also fitted as interfering absorbers in this window. The phase error and effective apodisation are adjusted during the non-linear least squares fitting retrieval and a second-order polynomial fit to the continuum level is allowed. This spectral region (from 2080 to $2270 \mathrm{~cm}^{-1}$ ) is reliant on the sensitivity provided by absorption bands of the second most abundant isotope $\left({ }^{13} \mathrm{CO}_{2}\right)$. Photosynthesis results in proportionally less ${ }^{13} \mathrm{C}$ in the vegetation that is burning than in the atmosphere, so reliance on ${ }^{13} \mathrm{CO}_{2}$ is likely to introduce a negative bias of between 0.5 and $2 \%$ depending on the type of vegetation and its main photosynthetic pathway. These biases are small compared to the total uncertainties (discussed in detail in Appendix B) and no attempt is made to correct for them. Comparisons show that mole fractions derived from this region are in good agreement (always $<5 \%$ ) with the results given by the region from 3520 to $3775 \mathrm{~cm}^{-1}$, which includes strong features for both ${ }^{12} \mathrm{CO}_{2}$ and ${ }^{13} \mathrm{CO}_{2}$. This latter region also has very strong $\mathrm{H}_{2} \mathrm{O}$ absorption and this leads to low signal-tonoise ratio and lower precision. For this reason, the 3520 $3775 \mathrm{~cm}^{-1}$ window was used only to confirm the accuracy of the chosen region for highly polluted atmospheres.

The accuracy of this retrieval method was tested using a series of dilutions of a calibration mixture (containing $1 \%$ of each of $\mathrm{CO}_{2}, \mathrm{CO}, \mathrm{CH}_{4}, \mathrm{C}_{2} \mathrm{H}_{2}, \mathrm{C}_{2} \mathrm{H}_{4}$ and $\mathrm{C}_{2} \mathrm{H}_{6}$,) measured with a White cell with an optical path of 22.2 metres, coupled to a Bomem MB-100 Series FTIR spectrometer similar to that used for the open-path measurements. The results showed that the spectral region from 3520 to $3775 \mathrm{~cm}^{-1}$ (with the strong $\mathrm{CO}_{2}$ and $\mathrm{H}_{2} \mathrm{O}$ absorptions) produced $\mathrm{CO}_{2}$ mole fractions within $1 \%$ of the true known calibration values. For very low mole fractions of $\mathrm{CO}_{2}$ (ambient levels and below in the $22.2 \mathrm{~m}$ White cell) the chosen region (from 2080 to $2270 \mathrm{~cm}^{-1}$ ) failed to retrieve accurate mole fractions. This was due to the combination of a short path length, low pressure and unusually low mole fractions producing very weak absorption features. However, within the range of absorbances used before and during the fires, the results are consistent between the two regions, demonstrating accuracy within $5 \%$. CO mole fractions retrieved from the chosen spectral region (from 2080 to $2270 \mathrm{~cm}^{-1}$ ) were within $2 \%$ of the true known calibration values. It should be noted that these uncertainties are only one contributor to the total uncertainty budget, which is described in detail later in this paper. These results for the calibration of $\mathrm{CO}_{2}$ and $\mathrm{CO}$ are consistent with the open-path calibration results of Smith et al. (2011). 


\section{A3 Spectral regions and parameters for fitting other trace gases}

A single standardised region was chosen to fit ethylene $\left(\mathrm{C}_{2} \mathrm{H}_{4}\right)$ and ammonia $\left(\mathrm{NH}_{3}\right)$ together from 920 to $1000 \mathrm{~cm}^{-1}$, with water also retrieved as an interfering species. Phase error and effective apodisation were both adjusted during the retrieval to optimise the fit, and the continuum level was fitted using a second-order polynomial.

Standardised region fitting phase error, effective apodisation and a second-order polynomial to the continuum level were also chosen for methane $\left(\mathrm{CH}_{4}\right)$ from 2980 to $3105 \mathrm{~cm}^{-1}$, (with $\mathrm{H}_{2} \mathrm{O}$ also retrieved) and for formic acid ( $\mathrm{HCOOH}$ ) from 1060 to $1150 \mathrm{~cm}^{-1}$ with $\mathrm{H}_{2} \mathrm{O}$ and $\mathrm{NH}_{3}$ also retrieved as interfering species. It should be noted that this relatively wide window from 1060 to $1150 \mathrm{~cm}^{-1}$ incorporates $\mathrm{P}, \mathrm{Q}$ and $\mathrm{R}$ branches of $\mathrm{HCOOH}$ and gave significantly better fits to the spectra showing the highest mole fractions (i.e. the smokiest spectra), fitting the $\mathrm{NH}_{3}$ interference and the continuum level curvature much better than a narrower window $\left(1098-1114 \mathrm{~cm}^{-1}\right)$ trialled first.

Both methanol $\left(\mathrm{CH}_{3} \mathrm{OH}\right)$ and formaldehyde $\left(\mathrm{H}_{2} \mathrm{CO}\right)$ were retrieved fitting only the phase error (with the effective apodisation fixed at zero since this produced a more stable fit for these broad absorbers), and a second-order polynomial fitted to the continuum level. The spectral region fitted to retrieve $\mathrm{H}_{2} \mathrm{CO}$ was $2710-2810 \mathrm{~cm}^{-1}$ with interfering $\mathrm{H}_{2} \mathrm{O}$ also retrieved and from 920 to $980 \mathrm{~cm}^{-1}$ for $\mathrm{CH}_{3} \mathrm{OH}$ with $\mathrm{H}_{2} \mathrm{O}$ and $\mathrm{NH}_{3}$ also fitted as interfering species.

Acetic acid $\left(\mathrm{CH}_{3} \mathrm{COOH}\right)$ is not available in the HITRAN database and so a library spectrum was used as the basis function for the absorption coefficients (Hurst et al., 1996; Sharpe et al., 2004). Both phase error and effective apodisation were fitted but only a simple slope in continuum level was permitted in the fit because a second-order polynomial fit to the continuum level interfered with the correct retrieval of the shallow absorption of acetic acid. The region chosen was $1130-1230 \mathrm{~cm}^{-1}$ and $\mathrm{H}_{2} \mathrm{O}, \mathrm{NH}_{3}$ and $\mathrm{HCOOH}$ were fitted as interfering species.
The region from 2971 to $3002 \mathrm{~cm}^{-1}$ was used to fit weak $\mathrm{C}_{2} \mathrm{H}_{6}$ absorption features, fitting $\mathrm{H}_{2} \mathrm{O}, \mathrm{CH}_{4}$ and $\mathrm{C}_{2} \mathrm{H}_{4}$ as interfering species, a second-order polynomial fitted to the background and allowing only the phase to vary (with the effective apodisation fixed since this produced a more stable retrieval for this weak absorber). The absorption features were too weak in most spectra to produce a stable fit and so results are provided from a single fire where the strongest trace gas enhancements were measured.

Table 1 summarises all the spectral regions and parameters used in this study, along with another region from 710 to $760 \mathrm{~cm}^{-1}$ used to derive acetylene $\left(\mathrm{C}_{2} \mathrm{H}_{2}\right)$ and hydrogen cyanide (HCN) in spectra recorded at savanna burns in Northern Australia and reported in the partner paper (Smith et al., 2014). These gases could not be retrieved from the spectra measured in this study because the particular mercury cadmium telluride (MCT) detector used had insufficient sensitivity in this spectral region. (MCT detectors have different optical cut-offs and the sensitivity of the MCT used in the savanna fires study extends to longer wavelengths than the one used for the forest fires described in this paper).

Example fits for all of the spectral regions used are given in Fig. 2. 


\section{Appendix B: Details of uncertainty estimates}

\section{B1 Uncertainties in $\triangle \mathrm{CO}_{2}$ and $\Delta \mathrm{CO}$}

An uncertainty budget was first calculated for $\Delta\left[\mathrm{CO}_{2}\right]$ and $\Delta[\mathrm{CO}]$ and then applied to the resulting emission factors calculated. The dominant uncertainty for both $\Delta\left[\mathrm{CO}_{2}\right]$ and $\Delta[\mathrm{CO}]$ is the assumed temperature, which causes both a spectral error (because the wrong line shape and line strengths are assumed in the fitting algorithm) and a density error, due to assuming the wrong air density when converting from the measured concentration in the line of path to mole fraction. The temperature was measured at a single point close to the spectrometer but in reality the temperature may vary substantially across the spectrometer's line of sight with a significant probability of increased temperatures where there are enhanced amounts of trace gases absorbing such as in the flaming emissions from the fire. However, flames are unlikely to cover the whole path length and so we estimated that the temperature error was likely to be approximately $20^{\circ} \mathrm{C}$. This estimate is meant to account for the possibility that a large temperature error for a fraction of the path may be more significant than a smaller temperature error over the entire path. Very large errors in the temperature are expected to produce easily identified effects like large errors in the spectral fits, or anomalous behaviour in the correlation plots. (The latter effect was identified for $\mathrm{CH}_{4}$ and $\mathrm{NH}_{3}$ in a subset of spectra from Alfords Point and these spectra were removed before calculating emission ratios.) The resulting density error was calculated assuming ideal gas behaviour and the spectral errors were taken from the sensitivity studies undertaken by Smith et al. (2011). The different temperature errors are obviously correlated and so the combined uncertainty was determined by some basic sensitivity studies. In the case of $\mathrm{CO}_{2}$ the density and spectral temperature errors are in the same direction giving a combined error of $15.3 \%$ for an underestimation of the temperature of $20^{\circ} \mathrm{C}$, whereas for $\mathrm{CO}$ they partially compensate giving an overall temperature error of $5.1 \%$. These combined temperature uncertainties are added in quadrature from those resulting from uncertainties in the assumed background mole fractions, spectral fitting errors and errors in the HITRAN lines used in the retrieval. The resulting overall uncertainty estimates are $16.3 \%$ for $\Delta\left[\mathrm{CO}_{2}\right]$ and $6.3 \%$ for $\Delta[\mathrm{CO}]$, and the contributions are summarised in Table B1.

\section{B2 Uncertainties in $\mathrm{EF}_{\mathrm{CO}_{2}}$ and $\mathrm{EF}_{\mathrm{CO}}$}

However, the resulting uncertainty in the emission factor calculated for $\mathrm{CO}_{2}$ is very different because it depends upon the ratio $C_{i} / C_{\mathrm{T}}$ - i.e. the ratio of $\Delta\left[\mathrm{CO}_{2}\right]$ to the sum of $\Delta\left[\mathrm{CO}_{2}\right], \Delta[\mathrm{CO}]$, and the other carbon-containing species. Since $\Delta\left[\mathrm{CO}_{2}\right]$ is the dominant term in both the numerator and the denominator, uncertainties in this value are largely cancelled out, leaving an uncertainty in the ratio
Table B1. Totals and component values of the uncertainty budget for calculating $\Delta\left[\mathrm{CO}_{2}\right]$ and $\Delta[\mathrm{CO}]$.

\begin{tabular}{lrrrrr}
\hline Gas & $\begin{array}{r}\text { Background } \\
\text { mole } \\
\text { fraction }\end{array}$ & $\begin{array}{r}\text { Total } \\
\text { temperature } \\
\text { error }\end{array}$ & $\begin{array}{r}\text { Spectral } \\
\text { fitting } \\
\text { error }\end{array}$ & $\begin{array}{r}\text { HITRAN } \\
\text { error }\end{array}$ & $\begin{array}{r}\text { Summed } \\
\text { in } \\
\text { quadrature }\end{array}$ \\
\hline$\Delta \mathrm{CO}_{2}$ & $2.5 \%$ & $15.3 \%$ & $1 \%$ & $5 \%$ & $16.3 \%$ \\
$\Delta \mathrm{CO}$ & $2.5 \%$ & $5.1 \%$ & $2 \%$ & $2 \%$ & $6.3 \%$ \\
\hline
\end{tabular}

Table B2. Totals and component values of the uncertainty budget for calculating $\mathrm{EF}_{\mathrm{CO}_{2}}$ and $\mathrm{EF}_{\mathrm{CO}}$.

\begin{tabular}{lccc}
\hline & $\begin{array}{c}\text { Uncertainty } \\
\text { in } C_{i} / C_{\mathrm{T}}\end{array}$ & $\begin{array}{c}\text { Uncertainty } \\
\text { in } F_{\mathrm{C}}\end{array}$ & $\begin{array}{c}\text { Summed in } \\
\text { quadrature }\end{array}$ \\
\hline $\mathrm{EF}_{\mathrm{CO}_{2}}$ & $1.5 \%$ & $10 \%$ & $10 \%$ \\
$\mathrm{EF}_{\mathrm{CO}}$ & $15 \%$ & $10 \%$ & $16 \%$ \\
\hline
\end{tabular}

$C_{\mathrm{CO}_{2}} / C_{\mathrm{T}} \leq 1.5 \%$. For $\mathrm{CO}$, the opposite scenario is true because the uncertainties in $\Delta\left[\mathrm{CO}_{2}\right]$ and $\Delta[\mathrm{CO}]$ combine to produce an uncertainty in the ratio $C_{\mathrm{CO}} / C_{\mathrm{T}} \leq 15 \%$.

Uncertainties in the molecular masses are vanishingly small but there is a large uncertainty in the carbon content of the fuel $\left(F_{\mathrm{C}}\right)$ which is not measured but taken to be $0.50 \pm 0.05$. This value of 0.5 is the same as that used by Bennett et al. (2013), and our estimated uncertainties encompasses the value used for the fuel fraction from trees by Volkova and Weston (2013) of 0.47 taken from the IPCC (2004) and the mean values measured by Burling et al. (2010) of $0.51 \pm 0.03$ for fuels from southern USA. The carbon content of the fuel turns out to be the dominant uncertainty for calculating the emission factor for $\mathrm{CO}_{2}$ and a major uncertainty in the emission factor for $\mathrm{CO}$. The resulting overall uncertainty estimates are $10 \%$ for $\mathrm{EF}_{\mathrm{CO}_{2}}$ and $16 \%$ for $\mathrm{EF}_{\mathrm{CO}}$, and the contributions are summarised in Table B2.

\section{B3 Uncertainties in emission ratios}

Uncertainties in the emission ratios are calculated from the relevant uncertainties in the gradient of the correlation plot of target gas and reference gas. The generalised least squares regression yields an uncertainty in the gradient but this value contains only random uncertainty and assumes that the uncertainties of each point are uncorrelated. Thus other factors that contribute to the uncertainty must also be considered. Table B3 shows the contributing factors to the uncertainties of the derived emission ratios, broken into contributions from the target gas $(\Delta$ gas $)$ and the reference gas $(\Delta$ ref $)-\mathrm{CO}_{2}$ or $\mathrm{CO}$. Component values for the uncertainties arising from spectral temperature sensitivities are estimated by assuming a maximum $20^{\circ} \mathrm{C}$ temperature error and adding sensitivities of target gas and reference gas in quadrature. (Whilst these errors are clearly not uncorrelated, the true correlation of the sensitivities of each gas are complicated by strong non-linearity and by feedbacks into the spectral fitting errors. 
Table B3. Totals and component values of the uncertainty budget for calculating emission ratios.

\begin{tabular}{|c|c|c|c|c|c|c|c|}
\hline $\begin{array}{l}\text { Emission } \\
\text { ratio }\end{array}$ & $\begin{array}{r}\text { Temperature } \\
\text { uncertainty (spectral) } \\
\text { for } 20^{\circ} \mathrm{C}\end{array}$ & $\begin{array}{r}\text { Spectral } \\
\text { fitting } \\
\text { uncertainty }\end{array}$ & $\begin{array}{r}\text { HITRAN } \\
\text { uncertainty }\end{array}$ & $\begin{array}{r}\text { Uncertainty } \\
\text { in } \\
\text { gradient }\end{array}$ & $\begin{array}{r}\Delta \text { gas } \\
\text { total } \\
\text { uncertainty }\end{array}$ & $\begin{array}{r}\Delta \text { ref } \\
\text { total } \\
\text { uncertainty }\end{array}$ & $\begin{array}{r}\text { Total } \\
\text { emission ratio } \\
\text { uncertainty }\end{array}$ \\
\hline $\mathrm{C}_{2} \mathrm{H}_{4} / \mathrm{CO}_{2}$ & $12 \%$ & $5 \%$ & $5 \%$ & $1 \%$ & $14 \%$ & $10 \%$ & $17 \%$ \\
\hline $\mathrm{H}_{2} \mathrm{CO} / \mathrm{CO}_{2}$ & $6.4 \%$ & $5 \%$ & $5 \%$ & $1.4 \%$ & $10 \%$ & $10 \%$ & $14 \%$ \\
\hline $\mathrm{N}_{2} \mathrm{O} / \mathrm{CO}_{2}$ & $5 \%$ & $4 \%$ & $5 \%$ & $5 \%$ & $10 \%$ & $10 \%$ & $14 \%$ \\
\hline $\mathrm{CH}_{4} / \mathrm{CO}$ & $4.4 \%$ & $2 \%$ & $5 \%$ & $0.8 \%$ & $7 \%$ & $3 \%$ & $8 \%$ \\
\hline $\mathrm{CH}_{3} \mathrm{OH} / \mathrm{CO}$ & $4.4 \%$ & $6 \%$ & $5 \%$ & $0.8 \%$ & $9 \%$ & $3 \%$ & $9 \%$ \\
\hline $\mathrm{CH}_{3} \mathrm{COOH} / \mathrm{CO}$ & $10 \% *$ & $3 \%$ & $10 \% *$ & $0.6 \%$ & $14 \%$ & $3 \%$ & $15 \%$ \\
\hline $\mathrm{NH}_{3} / \mathrm{CO}$ & $10.8 \%$ & $2 \%$ & $5 \%$ & $0.5 \%$ & $12 \%$ & $3 \%$ & $12 \%$ \\
\hline $\mathrm{HCOOH} / \mathrm{CO}$ & $8 \%$ & $16 \%$ & $5 \%$ & $5.4 \%$ & $19 \%$ & $3 \%$ & $20 \%$ \\
\hline $\mathrm{C}_{2} \mathrm{H}_{6} / \mathrm{CO}$ & $9.2 \%$ & $25 \%$ & $5 \%$ & $2.6 \%$ & $27 \%$ & $3 \%$ & $27 \%$ \\
\hline
\end{tabular}

* For $\mathrm{CH}_{3} \mathrm{COOH}$ values for the spectral temperature sensitivity and the HITRAN uncertainty and are not available or not relevant and instead an estimated value of $10 \%$ is assigned to both the spectral temperature uncertainty and to the uncertainty in the library spectrum cross sections (equivalent to a HITRAN error) so that an estimate may be obtained for the overall emission ratio uncertainty.

Thus adding in quadrature provides a very approximate estimate commensurate with the other difficulties in obtaining a good estimate of our true measurement uncertainty.)

Relevant spectral sensitivities and uncertainties in the HITRAN database are taken from the literature where available (Paton-Walsh et al., 2005; Pinnock and Shine, 1998; Rothman et al., 2009; Smith et al., 2011). For $\mathrm{CH}_{3} \mathrm{COOH}$ these values are not available and an estimated value of $10 \%$ is assigned to both the spectral temperature uncertainty and to the uncertainty in the library spectrum cross sections (equivalent to a HITRAN error). Uncertainties in the derived gradients were taken from the generalised least squares regressions (using data from the fire that yielded the worst $R^{2}$ values - so as to provide a worst-case scenario). The spectral fitting uncertainty estimated during the MALT fitting algorithm is also included because this is often not random but dominated by errors in the forward model.

Uncertainties in the reference gases ( $\Delta$ ref) were calculated using the components in Table B1, but excluding the uncertainties in background mole fractions and the error in density correction arising from temperature uncertainties. These components are excluded because the former does not contribute to the gradient and the latter cancels out as it produces the same error in the target gas and the reference gas. This yields an uncertainty in $\Delta$ ref of $10 \%$ for $\mathrm{CO}_{2}$ and $3 \%$ for $\mathrm{CO}$. Finally, all uncertainties are added in quadrature to give a total uncertainty for each emission ratio (see Table B3).

\section{B4 Uncertainties in emission factors}

Finally, measurement uncertainties in emission factors were determined for each trace gas by combining in quadrature the uncertainties in the emission ratio with the uncertainty in the emission factor of the relevant reference gas $\left(\mathrm{CO}_{2}\right.$ or $\left.\mathrm{CO}\right)$. These uncertainties are shown in parentheses in Table 4. For $\mathrm{CO}_{2}$ and $\mathrm{CO}$, the measurement uncertainty exceeds the fire to fire variability and so the uncertainty in the mean emission factor given is the measurement uncertainty. For all other gases, the fire-to-fire variability dominates and the quoted uncertainty in the emission factor is the $1 \sigma$ standard deviation of the mean. 
Acknowledgements. The authors would like to acknowledge the invaluable assistance of the New South Wales Department of Environment, Climate Change and Water for enabling us to make measurements at their hazard reduction burns. Particular thanks are due to S. Evans, B. Sullivan, D. Menzies-Jackson, R. Clark and L. Tasker. Thanks are also due to B. Yokelson, I. Burling, M. Cameron and M. Wooster for their input to discussions on best choices for spectral windows and methods for estimating whole-fire emission factors. We are also grateful to those within the Centre for Atmospheric Chemistry at the University of Wollongong who have supported this work in many ways before, during and after the fires - in particular D. Kubistin, G. Kettlewell, F. Phillips, T. Naylor, M. Riggenbach, and S. Wilson. Thanks are due to the Australian Research Council for funding this work as a small component of the Discovery Project DP110101948.

Edited by: P. Monks

\section{References}

Akagi, S. K., Yokelson, R. J., Wiedinmyer, C., Alvarado, M. J., Reid, J. S., Karl, T., Crounse, J. D., and Wennberg, P. O.: Emission factors for open and domestic biomass burning for use in atmospheric models, Atmos. Chem. Phys., 11, 4039-4072, doi:10.5194/acp-11-4039-2011, 2011.

Akagi, S. K., Craven, J. S., Taylor, J. W., McMeeking, G. R., Yokelson, R. J., Burling, I. R., Urbanski, S. P., Wold, C. E., Seinfeld, J. H., Coe, H., Alvarado, M. J., and Weise, D. R.: Evolution of trace gases and particles emitted by a chaparral fire in California, Atmos. Chem. Phys., 12, 1397-1421, doi:10.5194/acp-12-13972012, 2012.

Akagi, S. K., Yokelson, R. J., Burling, I. R., Meinardi, S., Simpson, I., Blake, D. R., McMeeking, G. R., Sullivan, A., Lee, T., Kreidenweis, S., Urbanski, S., Reardon, J., Griffith, D. W. T., Johnson, T. J., and Weise, D. R.: Measurements of reactive trace gases and variable $\mathrm{O}_{3}$ formation rates in some South Carolina biomass burning plumes, Atmos. Chem. Phys., 13, 1141-1165, doi:10.5194/acp-13-1141-2013, 2013.

Akagi, S. K., Burling, I. R., Mendoza, A., Johnson, T. J., Cameron, M., Griffith, D. W. T., Paton-Walsh, C., Weise, D. R., Reardon, J., and Yokelson, R. J.: Field measurements of trace gases emitted by prescribed fires in southeastern US pine forests using an open-path FTIR system, Atmos. Chem. Phys., 14, 199-215, doi:10.5194/acp-14-199-2014, 2014.

Alvarado, M. J., Cady-Pereira, K. E., Xiao, Y. P., Millet, D. B., and Payne V. H.: Emission Ratios for Ammonia and Formic Acid and Observations of Peroxy Acetyl Nitrate (PAN) and Ethylene in Biomass Burning Smoke as Seen by the Tropospheric Emission Spectrometer (TES), Atmosphere, 2, 633-654, 2011.

Andreae, M. O. and Merlet, P.: Emission of trace gases and aerosols from biomass burning, Global Biogeochem. Cy., 15, 955-966, 2001.

Australian Greenhouse Office: National greenhouse gas inventory 2004, Rep., Australian Government Department of the Environment and Heritage, 2006.

Bacsik, Z., Mink, J., and Keresztury, G.: FTIR spectroscopy of the atmosphere. I. Principles and methods, Appl. Spectrosc. Rev., 39, 295-363, 2004.
Bennett, L. T., Aponte, C., Tolhurst, K. G., Löw, M., and Baker, T. G.: Decreases in standing tree-based carbon stocks associated with repeated prescribed fires in a temperate mixed-species eucalypt forest, Forest Ecol. Manag., 306, 243-255, 2013.

Burling, I. R., Yokelson, R. J., Griffith, D. W. T., Johnson, T. J., Veres, P., Roberts, J. M., Warneke, C., Urbanski, S. P., Reardon, J., Weise, D. R., Hao, W. M., and de Gouw, J.: Laboratory measurements of trace gas emissions from biomass burning of fuel types from the southeastern and southwestern United States, Atmos. Chem. Phys., 10, 11115-11130, doi:10.5194/acp10-11115-2010, 2010.

Cottrill, D. A.: Seasonal climate summary southern hemisphere (spring 2011): La Nina returns, Aust. Meteorol. Oceanogr. J., 62, 179-192, 2012.

Giglio, L., Loboda, T., Roy, D. P., Quayle, B., and Justice, C. O.: An active-fire based burned area mapping algorithm for the MODIS sensor, Remote Sens. Environ., 113, 408-420, 2009.

Giglio, L., Randerson, J. T., and Van Der Werf, G. R.: Analysis of daily, monthly, and annual burned area using the fourthgeneration global fire emissions database (GFED4), J. Geophys. Res.-Biogeo., 118, 317-328, 2013.

Glatthor, N., Höpfner, M., Semeniuk, K., Lupu, A., Palmer, P. I., McConnell, J. C., Kaminski, J. W., von Clarmann, T., Stiller, G. P., Funke, B., Kellmann, S., Linden, A., and Wiegele, A.: The Australian bushfires of February 2009: MIPAS observations and GEM-AQ model results, Atmos. Chem. Phys., 13, 1637-1658, doi:10.5194/acp-13-1637-2013, 2013.

Goode, J. G., Yokelson, R. J., Susott, R. A., and Ward, D. E. Trace gas emissions from laboratory biomass fires measured by open-path Fourier transform infrared spectroscopy: Fires in grass and surface fuels, J. Geophys. Res.-Atmos., 104, 21237-21245, 1999.

Goode, J. G., Yokelson, R. J., Ward, D. E., Susott, R. A., Babbitt, R. E., Davies, M. A., and Hao, W. M.: Measurements of excess $\mathrm{O}_{3}, \mathrm{CO}_{2}, \mathrm{CO}, \mathrm{CH}_{4}, \mathrm{C}_{2} \mathrm{H}_{4}, \mathrm{C}_{2} \mathrm{H}_{2}, \mathrm{HCN}, \mathrm{NO}, \mathrm{NH}_{3}$, $\mathrm{HCOOH}, \mathrm{CH}_{3} \mathrm{COOH}, \mathrm{HCHO}$, and $\mathrm{CH}_{3} \mathrm{OH}$ in 1997 Alaskan biomass burning plumes by airborne Fourier transform infrared spectroscopy (AFTIR), J. Geophys. Res., 105, 22147-22166, doi:10.1029/2000jd900287, 2000.

Griffith, D. W. T.: Synthetic Calibration and Quantitative Analysis of Gas-Phase FT-IR Spectra, Appl. Spectrosc., 50, 59-70, 1996.

Griffith, D. W. T., Mankin, W. G., Coffey, M. T., Ward, D. E., and Riebau, A.: FTIR Remote Sensing of Biomass Burning Emissions of $\mathrm{CO}_{2}, \mathrm{CO}, \mathrm{CH}_{4} \mathrm{CH}_{2} \mathrm{O}, \mathrm{NO}, \mathrm{NO}_{2}, \mathrm{NH}_{3}$ and $\mathrm{N}_{2} \mathrm{O}$, in: Global Biomass Burning: Atmospheric, Climatic and Biospheric Implications, edited by: Levine, J. S., 230-239, MIT Press, Cambridge, 1991

Griffith, D. W. T., Deutscher, N. M., Caldow, C., Kettlewell, G., Riggenbach, M., and Hammer, S.: A Fourier transform infrared trace gas and isotope analyser for atmospheric applications, Atmos. Meas. Tech., 5, 2481-2498, doi:10.5194/amt-5-2481-2012, 2012.

Hao, W. M. and Ward, D. E.: Methane production from global biomass burning, J. Geophys. Res.-Atmos., 98, 20657-20661, 1993.

Haverd, V., Raupach, M. R., Briggs, P. R., J. G. Canadell., Davis, S. J., Law, R. M., Meyer, C. P., Peters, G. P., Pickett-Heaps, C., and Sherman, B.: The Australian terrestrial carbon budget, Biogeosciences, 10, 851-869, doi:10.5194/bg-10-851-2013, 2013. 
Hurst, D. F., Griffith, D. W. T., and Cook, G. D.: Trace gas emissions from biomass burning in tropical Australian savannas, J. Geophys. Res.-Atmos., 99, 16441-16456, 1994a.

Hurst, D. F., Griffith, D. W. T., Carras, J. N., Williams, D. J., and Fraser, P. J.: Measurements of trace gases emitted by Australian savanna fires during the 1990 dry season, J. Atmos. Chem., 18, 33-56, 1994b.

Hurst, D. F., Griffith, D. W. T., and Cook, G. D.: Trace-Gas Emissions from Biomass Burning in Australia, in: Biomass Burning and Global Change, edited by: Levine, J. S., The MIT Press, London, England, 1996.

IPCC: Good practice guidance for land use, land-use change and forestry (GPGLULUCF), Chapter 3, Rep., 2004.

Ito, A. and Penner J. E.: Global estimates of biomass burning emissions based on satellite imagery for the year 2000, J. Geophys. Res., 109, D14S05, doi:10.1029/2003jd004423, 2004.

Lobert, J. M. and Scharffe, D. H.: Experimental Evaluation of Biomass Burning Emissions, in: Global Biomass Burning: Atmospheric, Climatic, and Biospheric Implications, edited by: Levine, J. S., 289-304, MIT Press, Cambridge, 1991.

Maleknia, S. D., Bell, T. L., and Adams, M. A.: Eucalypt smoke and wildfires: Temperature dependent emissions of biogenic volatile organic compounds, Int. J. Mass Spectrom., 279, 126-133, 2009.

Meyer, C. P., Cook, G. D., Reisen, F., Smith, T. E. L., Tattaris, M., Russell-Smith, J., Maier, S. W., Yates, C. P., and Wooster, M. J.: Direct measurements of the seasonality of emission factors from savanna fires in northern Australia, J. Geophys. Res.Atmos., 117, D20305, doi:10.1029/2012jd017671, 2012.

Pak, B. C., Langenfelds, R. L., Young, S. A., Francey, R. J., Meyer, C. P., Kivlighon, L. M., Cooper, L. N., Dunse, B. L., Allison, C. E., Steele, L. P., Galbally, I. E., and Weeks, I. A.: Measurements of biomass burning influences in the troposphere over southeast Australia during the SAFARI 2000 dry season campaign, J. Geophys. Res.-Atmos., 108, 8480, doi:10.1029/2002jd002343, 2003.

Paton-Walsh, C., Jones, N., Wilson, S., Meier, A., Deutscher, N., Griffith, D., Mitchell, R., and Campbell, S.: Trace gas emissions from biomass burning inferred from aerosol optical depth, Geophys. Res. Lett., 31, L05116, doi:10.1029/2003g1018973, 2004.

Paton-Walsh, C., Jones, N. B., Wilson, S. R., Haverd, V., Meier, A., Griffith, D. W. T., and Rinsland, C. P.: Measurements of trace gas emissions from Australian forest fires and correlations with coincident measurements of aerosol optical depth, J. Geophys. Res.-Atmos., 110, D24305, doi:10.1029/2005jd006202, 2005.

Paton-Walsh, C., Wilson, S. R., Jones, N. B., and Griffith, D. W. T.: Measurement of methanol emissions from Australian wildfires by ground-based solar Fourier transform spectroscopy, Geophys. Res. Lett., 35, L08810, doi:10.1029/2007g1032951, 2008.

Paton-Walsh, C., Emmons, L. K., and Wilson, S. R.: Estimated total emissions of trace gases from the Canberra Wildfires of 2003: a new method using satellite measurements of aerosol optical depth \& the MOZART chemical transport model, Atmos. Chem. Phys., 10, 5739-5748, doi:10.5194/acp-10-5739-2010, 2010a.

Paton-Walsh, C., Deutscher, N. M., Griffith, D. W. T., Forgan, B. W., Wilson, S. R., Jones, N. B., and Edwards, D. P.: Trace gas emissions from savanna fires in northern Australia, J. Geophys. Res.-Atmos., 115, D16314, doi:10.1029/2009jd013309, 2010 b.

Paton-Walsh, C., Emmons, L. K., and Wiedinmyer, C.: Australia's Black Saturday fires - Comparison of techniques for estimating emissions from vegetation fires, Atmos. Environ., 60, 262-270, 2012.

Pfister, G., Hess, P. G., Emmons, L. K., Lamarque, J. F., Wiedinmyer, C., Edwards, D. P., Petron, G., Gille, J. C., and Sachse, G. W.: Quantifying CO emissions from the 2004 Alaskan wildfires using MOPITT CO data, Geophys. Res. Lett., 32, L11809, doi:10.1029/2005g1022995, 2005.

Phillips, F. A., Bai, M., Naylor, T., Bryan, G. R., Tonini, M., Jones, F. M., Malano, G., Pinares-Patino, C. S., and Griffith, D. W. T.: Methane emissions from a range of livestock management systems, estimated using the open-path FTIR Spectroscopy, paper presented at 4th International Conference on Greenhouse Gases and Animal Agriculture, edited by: Mc Geough, E. J., McGinn, S. M., and Banff, A. B., Canada, 2011.

Pinnock, S. and Shine, K. P.: The effects of changes in HITRAN and uncertainties in the spectroscopy on infrared irradiance calculations, J. Atmos. Sci., 55, 1950-1964, 1998.

Reisen, F. and Brown, S. K.: Australian firefighters' exposure to air toxics during bushfire burns of autumn 2005 and 2006, Environ. Int., 35, 342-352, 2009.

Reisen, F., Meyer, C. P., McCaw, L., Powell, J. C., Tolhurst, K., Keywood, M. D., and Gras, J. L.: Impact of smoke from biomass burning on air quality in rural communities in southern Australia, Atmos. Environ., 45, 3944-3953, 2011.

Rothman, L. S., Gordon, I. E., Barbe, A., Benner, D. C., Bernath, P. E., Birk, M., Boudon, V., Brown, L. R., Campargue, A., Champion, J. P., Chance, K., Coudert, L. H., Dana, V., Devi, V. M., Fally, S., Flaud, J. M., Gamache, R. R., Goldman, A., Jacquemart, D., Kleiner, I., Lacome, N., Lafferty, W. J., Mandin, J. Y., Massie, S. T., Mikhailenko, S. N., Miller, C. E., Moazzen-Ahmadi, N., Naumenko, O. V., Nikitin, A. V., Orphal, J., Perevalov, V. I., Perrin, A., Predoi-Cross, A., Rinsland, C. P., Rotger, M., Simeckova, M., Smith, M. A. H., Sung, K., Tashkun, S. A., Tennyson, J., Toth, R. A., Vandaele, A. C., and Vander Auwera, J.: The HITRAN 2008 molecular spectroscopic database, J. Quant. Spectrosc. Ra., 110, 533-572, 2009.

Seiler, W. and Crutzen, P. J.: Estimates of gross and net fluxes of carbon between the biosphere and atmosphere, Clim. Change, 2, 207-247, 1980.

Sharpe, S. W., Johnson, T. J., Sams, R. L., Chu, P. M., Rhoderick, G. C., and Johnson, P. A.: Gas-phase databases for quantitative infrared spectroscopy, Appl. Spectrosc., 58, 1452-1461, 2004.

Shirai, T., Blake, D. R., Meinardi, S., Rowland, F. S., Russell-Smith, J., Edwards, A., Kondo, Y., Koike, M., Kita, K., Machida, T., Takegawa, N., Nishi, N., Kawakami, S., and Ogawa, T.: Emission estimates of selected volatile organic compounds from tropical savanna burning in northern Australia, J. Geophys. Res., 108, 8406, doi:10.1029/2001jd000841, 2003.

Smith, T. E. L., Wooster, M. J., Tattaris, M., and Griffith, D. W. T.: Absolute accuracy and sensitivity analysis of OP-FTIR retrievals of $\mathrm{CO}_{2}, \mathrm{CH}_{4}$ and $\mathrm{CO}$ over concentrations representative of "clean air" and "polluted plumes", Atmos. Meas. Tech., 4, 97116, doi:10.5194/amt-4-97-2011, 2011.

Smith, T. E. L., Paton-Walsh, C., Meyer, C. P., Cook, G. D., Maier, S. W., Russell-Smith, J., Wooster, M. J., and Yates, C. P.: New emission factors for Australian vegetation fires measured using open-path Fourier transform infrared spectroscopy - Part 2: Australian tropical savanna fires, Atmos. Chem. Phys., 14, 1133511352, doi:10.5194/acp-14-11335-2014, 2014. 
Tobin, S. and Skinner, T. C. L.: Seasonal climate summary southern hemisphere (autumn 2011): one of the strongest La Nina events on record begins to decline, Aust. Meteorol. Oceanogr. J., 62, 39-50, 2012.

van der Werf, G. R., Randerson, J. T., Giglio, L., Collatz, G. J., Kasibhatla, P. S., and Arellano Jr., A. F.: Interannual variability in global biomass burning emissions from 1997 to 2004, Atmos. Chem. Phys., 6, 3423-3441, doi:10.5194/acp-6-3423-2006, 2006.

van der Werf, G. R., Randerson, J. T., Giglio, L., Collatz, G. J., Mu, M., Kasibhatla, P. S., Morton, D. C., DeFries, R. S., Jin, Y., and van Leeuwen, T. T.: Global fire emissions and the contribution of deforestation, savanna, forest, agricultural, and peat fires (19972009), Atmos. Chem. Phys., 10, 11707-11735, doi:10.5194/acp10-11707-2010, 2010.

van Leeuwen, T. T., Peters, W., Krol, M. C., and van der Werf, G. R.: Dynamic biomass burning emission factors and their impact on atmospheric CO mixing ratios, J. Geophys. Res.-Atmos., 118, 6797-6815, 2013.

Volkova, L. and Weston, C.: Redistribution and emission of forest carbon by planned burning in Eucalyptus obliqua (L. Herit.) forest of south-eastern Australia, Forest. Ecol. Manag., 304, 383390, 2013.

Ward, D. E. and Radke, L. F.: Emissions measurements from vegetation fires: A comparative evaluation of methods and results, in: Fire in the Environment: The Ecological, Atmospheric and Climatic Importance of Vegetation Fires, edited by: Crutzen, P. J. and Goldammer, J. G., 15 July 1993, 53-76, 1993.

Wiedinmyer, C., Akagi, S. K., Yokelson, R. J., Emmons, L. K., AlSaadi, J. A., Orlando, J. J., and Soja, A. J.: The Fire INventory from NCAR (FINN): a high resolution global model to estimate the emissions from open burning, Geosci. Model Dev., 4, 625641, doi:10.5194/gmd-4-625-2011, 2011.

Wooster, M. J., Zhukov, B., and Oertel, D.: Fire radiative energy for quantitative study of biomass burning: derivation from the BIRD experimental satellite and comparison to MODIS fire products, Remote Sens. Environ., 86, 83-107, 2003.

Wooster, M. J., Roberts, G., Perry, G. L. W., and Kaufman, Y. J.: Retrieval of biomass combustion rates and totals from fire radiative power observations: FRP derivation and calibration relationships between biomass consumption and fire radiative energy release, J. Geophys. Res.-Atmos., 110, D24311, doi:10.1029/2005jd006318, 2005.

Wooster, M. J., Freeborn, P. H., Archibald, S., Oppenheimer, C., Roberts, G. J., Smith, T. E. L., Govender, N., Burton, M., and Palumbo, I.: Field determination of biomass burning emission ratios and factors via open-path FTIR spectroscopy and fire radiative power assessment: headfire, backfire and residual smouldering combustion in African savannahs, Atmos. Chem. Phys., 11, 11591-11615, doi:10.5194/acp-11-11591-2011, 2011.
Yokelson, R. J., Griffith, D. W. T., and Ward, D. E.: Openpath Fourier transform infrared studies of large-scale laboratory biomass fires, J. Geophys. Res., 101, 21067-21080, 1996.

Yokelson, R. J., Susott, R., Ward, D. E., Reardon, J., and Griffith, D. W. T.: Emissions from smoldering combustion of biomass measured by open-path Fourier transform infrared spectroscopy, J. Geophys. Res., 102, 18865-18877, doi:10.1029/97jd00852, 1997.

Yokelson, R. J., Goode, J. G., Ward, D. E., Susott, R. A., Babbitt, R. E., Wade, D. D., Bertschi, I., Griffith, D. W. T., and Hao, W. M.: Emissions of formaldehyde, acetic acid, methanol, and other trace gases from biomass fires in North Carolina measured by airborne Fourier transform infrared spectroscopy, J. Geophys. Res.Atmos., 104, 30109-30125, 1999.

Yokelson, R. J., Karl, T., Artaxo, P., Blake, D. R., Christian, T. J., Griffith, D. W. T., Guenther, A., and Hao, W. M.: The Tropical Forest and Fire Emissions Experiment: overview and airborne fire emission factor measurements, Atmos. Chem. Phys., 7, 5175-5196, doi:10.5194/acp-7-5175-2007, 2007.

Yokelson, R. J., Crounse, J. D., DeCarlo, P. F., Karl, T., Urbanski, S., Atlas, E., Campos, T., Shinozuka, Y., Kapustin, V., Clarke, A. D., Weinheimer, A., Knapp, D. J., Montzka, D. D., Holloway, J., Weibring, P., Flocke, F., Zheng, W., Toohey, D., Wennberg, P. O., Wiedinmyer, C., Mauldin, L., Fried, A., Richter, D., Walega, J., Jimenez, J. L., Adachi, K., Buseck, P. R., Hall, S. R., and Shetter, R.: Emissions from biomass burning in the Yucatan, Atmos. Chem. Phys., 9, 5785-5812, doi:10.5194/acp-9-5785-2009, 2009.

Yokelson, R. J., Burling, I. R., Gilman, J. B., Warneke, C., Stockwell, C. E., de Gouw, J., Akagi, S. K., Urbanski, S. P., Veres, P., Roberts, J. M., Kuster, W. C., Reardon, J., Griffith, D. W. T., Johnson, T. J., Hosseini, S., Miller, J. W., Cocker III, D. R., Jung, H., and Weise, D. R.: Coupling field and laboratory measurements to estimate the emission factors of identified and unidentified trace gases for prescribed fires, Atmos. Chem. Phys., 13, 89-116, doi:10.5194/acp-13-89-2013, 2013.

Young, E. and Paton-Walsh, C.: Emission ratios of the tropospheric ozone precursors nitrogen dioxide and formaldehyde from Australia's black saturday fires, Atmosphere, 2, 617-632, 2011. 